INTER NATIONAL MONETARY FUND
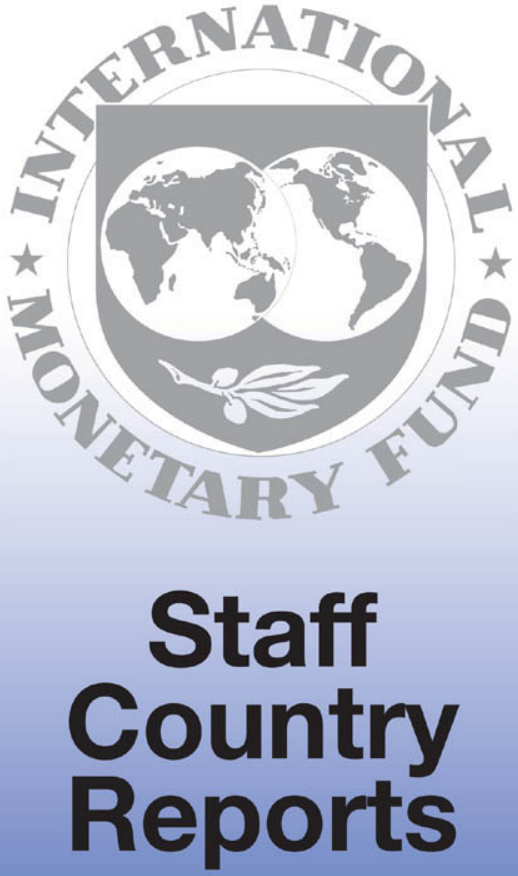
Iceland: 2002 Article IV Consultation-Staff Report; Public Information Notice on the Executive Board Discussion; and Statement by the Executive Director for Iceland

Under Article IV of the IMF's Articles of Agreement, the IMF holds bilateral discussions with members, usually every year. In the context of the 2002 Article IV consultation with Iceland, the following documents have been released and are included in this package:

- the staff report for the 2002 Article IV consultation, prepared by a staff team of the IMF, following discussions that ended on March 27, 2002, with the officials of Iceland on economic developments and policies. Based on information available at the time of these discussions, the staff report was completed on May 21, 2002. The views expressed in the staff report are those of the staff team and do not necessarily reflect the views of the Executive Board of the IMF.

- a Public Information Notice (PIN) summarizing the views of the Executive Board as expressed during its June 21, 2002 discussion of the staff report that concluded the Article IV consultation.

- a statement by the Executive Director for Iceland.

The document(s) listed below have been or will be separately released.

\section{Selected Issues Paper}

The policy of publication of staff reports and other documents allows for the deletion of market-sensitive information.

To assist the IMF in evaluating the publication poliey, reader comments are invited and may be sent by e-mail to Publicationpolicy@imf.org.

Copies of this report are available to the public from

International Monetary Fund - Publication Services

$70019^{\text {th }}$ Street, N.W. - Washington, D.C. 20431

Telephone: (202) 623-7430 - Telefax: (202) 623-7201

E-mail: publications@imf.org Internet: http://www.imf.org

Price: $\$ 15.00$ a copy

\section{International Monetary Fund}

Washington, D.C. 
This page intentionally left blank

CInternational Monetary Fund. Not for Redistribution 
INTERNATIONAL MONETARY FUND

ICELAND

\section{Staff Report for the 2002 Article IV Consultation}

Prepared by the Staff Representatives for the 2002 Consultation with Iceland Approved by Alessandro Leipold and Martin Fetherston

May 21,2002

- The Article IV consultation discussions were held in Reykjavik during March 18-27, 2002. The mission comprised Messrs. Escolano (Head), Engels, Gapen (EU1), Kupiec, and Song (MAE). Mr. Isleifsson, Executive Director for Iceland, participated in the discussions. Staff met with the Chairman of the Board of Governors of the Central Bank of Iceland (CBI), Secretaries General of the Prime Minister's Office and the Ministry of Finance, Permanent Secretary of the Ministry of Fisheries, Director General of the Financial Supervisory Authority (FSA), and other senior government officials; representatives of the Icelandic Federation of Labor, Confederation of Icelandic Employers, financial institutions, and academics.

- Iceland has accepted the obligations of Article VIII, Sections 2,3, and 4. The exchange system is free of restrictions on payments and transfers for current international transactions (Appendix II).

- Iceland has subscribed to the Special Data Dissemination Standard (SDDS), and data provision is adequate for conducting surveillance (Appendix III).

- The authorities released the mission's concluding statement and have agreed to publish the staff report.

At the conclusion of the last consultation in May 2001, Executive Directors conmended the authorities for Iceland's strong long-term economic performance and welcomed the authorities' adoption of inflation targeting and the floating of the króna. Directors noted, however, the sustained overheating of the economy and, in light of the findings of the Financial System Stability Assessment (FSSA), recommended measures to lower the risk exposure of the financial system. Against this background, the Executive Board moved Iceland temporarily to a 12-month consultation cycle.

- A center-right coalition has been in government since 1991. The next elections are scheduled for May 2003. 


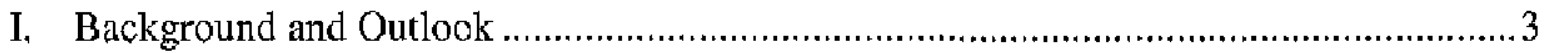

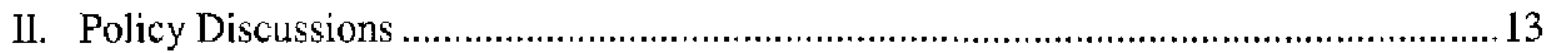

A. Financial Sector Policies ..............................................................................13

B. Monetary Policy .......................................................................................14

C. Fiscal Policy.......................................................................................... 20

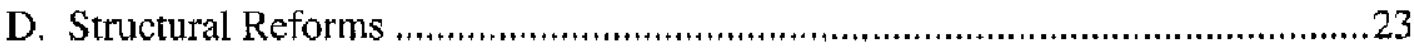

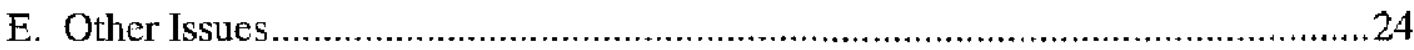

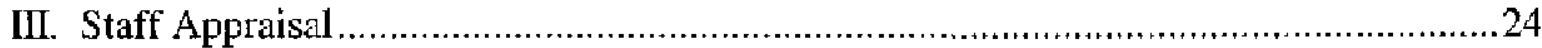

Tables

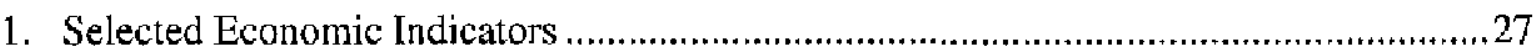

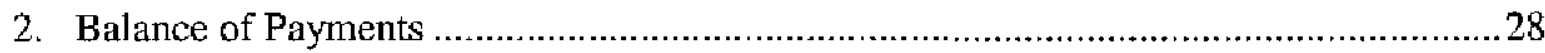

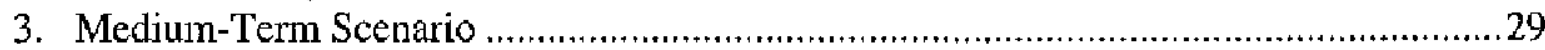

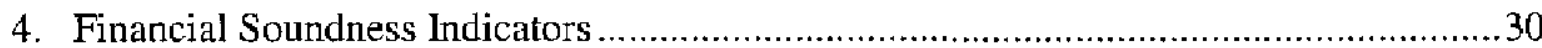

5. Indicators of External and Financial Vulnerability .....................................................32

6. Summary Operations of the General Government ..................................................33

Figures

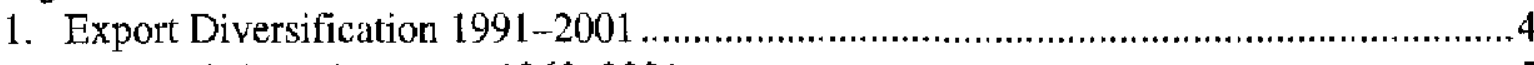

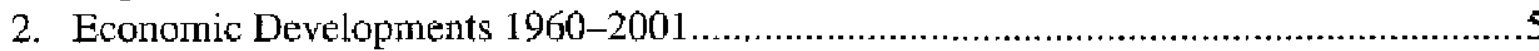

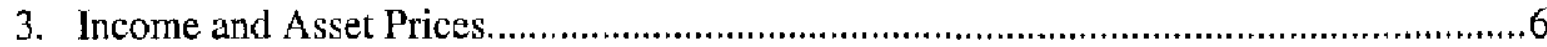

4. Saving, Investment, and Contribution to Growth ................................................

5. Exchange Rate and Competitiveness ................................................................9

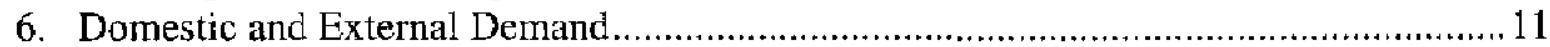

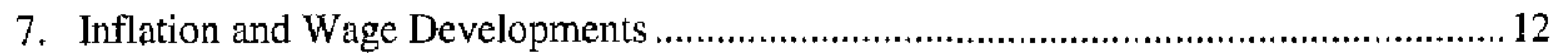

8. Interest Rate Developments............................................................................... 16

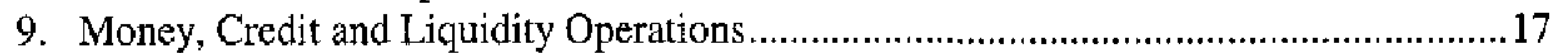

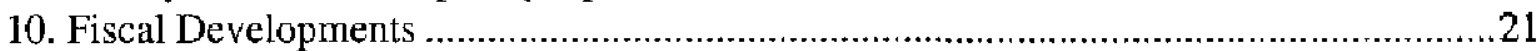

Text Box

Exchange Rate Pass-Through and Monetary Policy Transmission Mechanism ..........19

Annex

Financial Sector Developments

Appendices

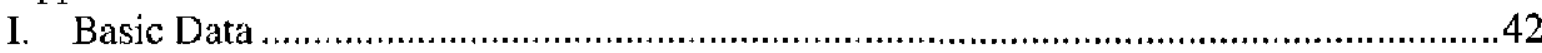

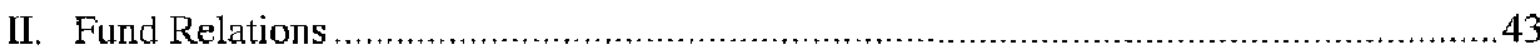

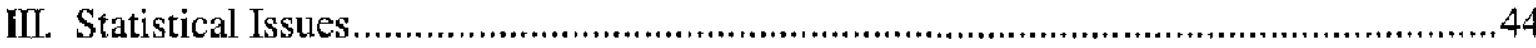

Core Statistical Indicators …......................................................................45 


\section{BACKGROUND AND OUTLOOK}

1. The overall growth performance of the leelandic economy during the last decade has been impressive. During 1992-2001, output increased by 37 percent and, in 2001, GDP per capita (at purchasing parity prices) reached US\$29,000, among the highest in the OECD. This performance owes much to the authorities' policies, adopted since the early-1990s, of market liberalization, public sector rationalization, privatization, and other structural reforms that fostered entrepreneurship, investment, and growth. As a consequence, Iceland has made significant headway in diversifying exports, although it remains exposed to destabilizing external shocks

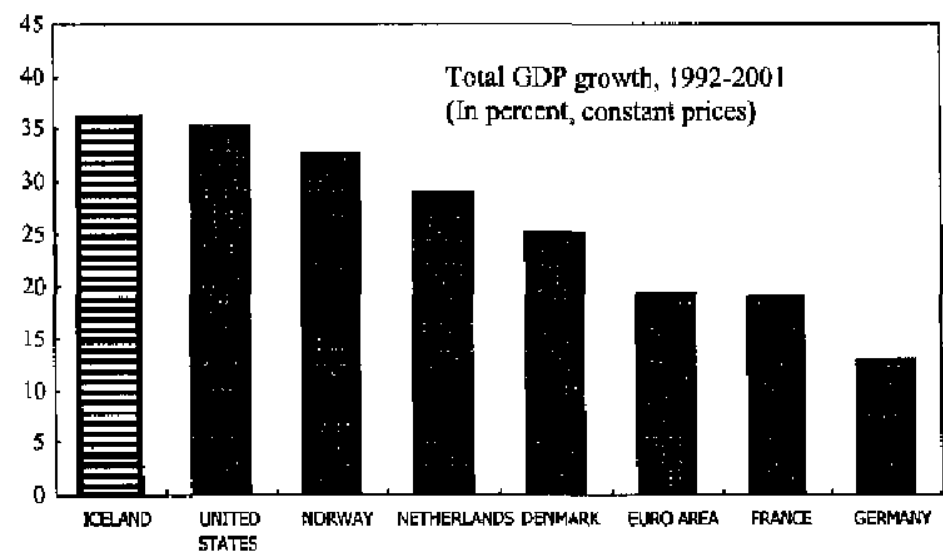
(Figure 1). The successful disinflation of the early part of the 1990 s and macroeconomic policies that emphasized stability and predictability set the stage for the economic expansion that developed since 1994 (Figure 2). Financial opening gathered momentum in 1994 with the creation of the European Economic Area, of which Iceland is a founding member, and which led to a full liberalization of financial markets and the capital account by 1995 . Also key was the

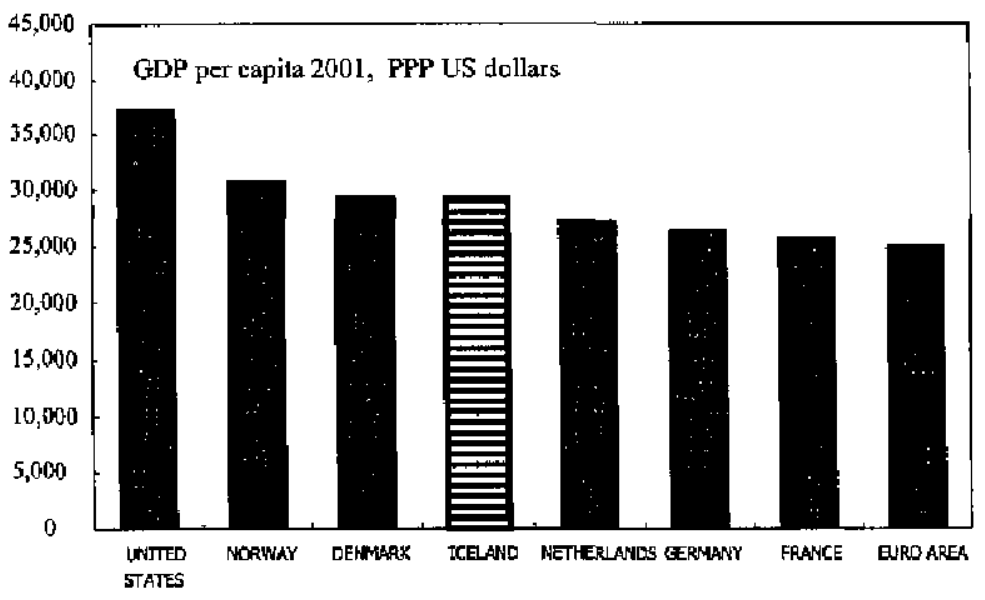
authorities' determination to consolidate the public finances, turning earlier budget deficits into surpluses, reducing the net government debt, and setting aside funds to cover future public pension obligations.

2. The rapid expansion of the second half of the 1990s, however, led eventually to overheating, a build-up of domestic and external imbalances, and the emergence of financial sector vulnerabilities. By about 1998, the expansion initially sparked by burgeoning investment in power-intensive industries and a recovery in fish stocks-m-had developed into a consumption boom (Table 1 and Figure 3). Inflationary pressures emerged and the current account deficit widened, peaking at 10 percent of GDP in 2000 (Figure 4). Growing budgetary surpluses and interest rate hikes during 1998-2000 failed to cool down the economy. Instead, positive interest rate differentials and the perception of low exchange 
Figure 1. Iceland: Export Diversification 1991-2001

(In percent of total exports of goods and services)
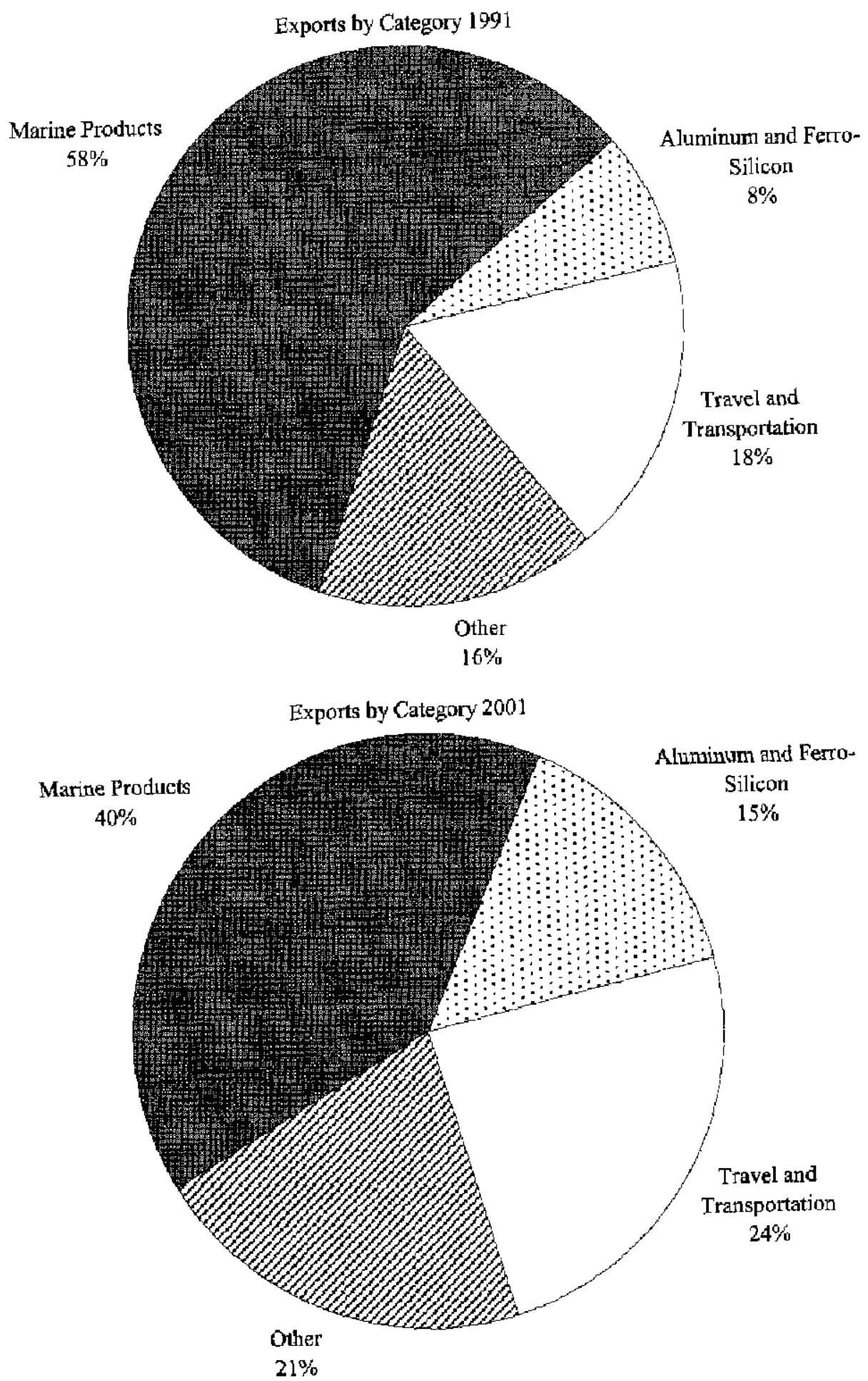

Sources: Statistics Iceland; Central Batnk of Iceland. 
Figure 2. Iceland: Economic Developments 1960-2001
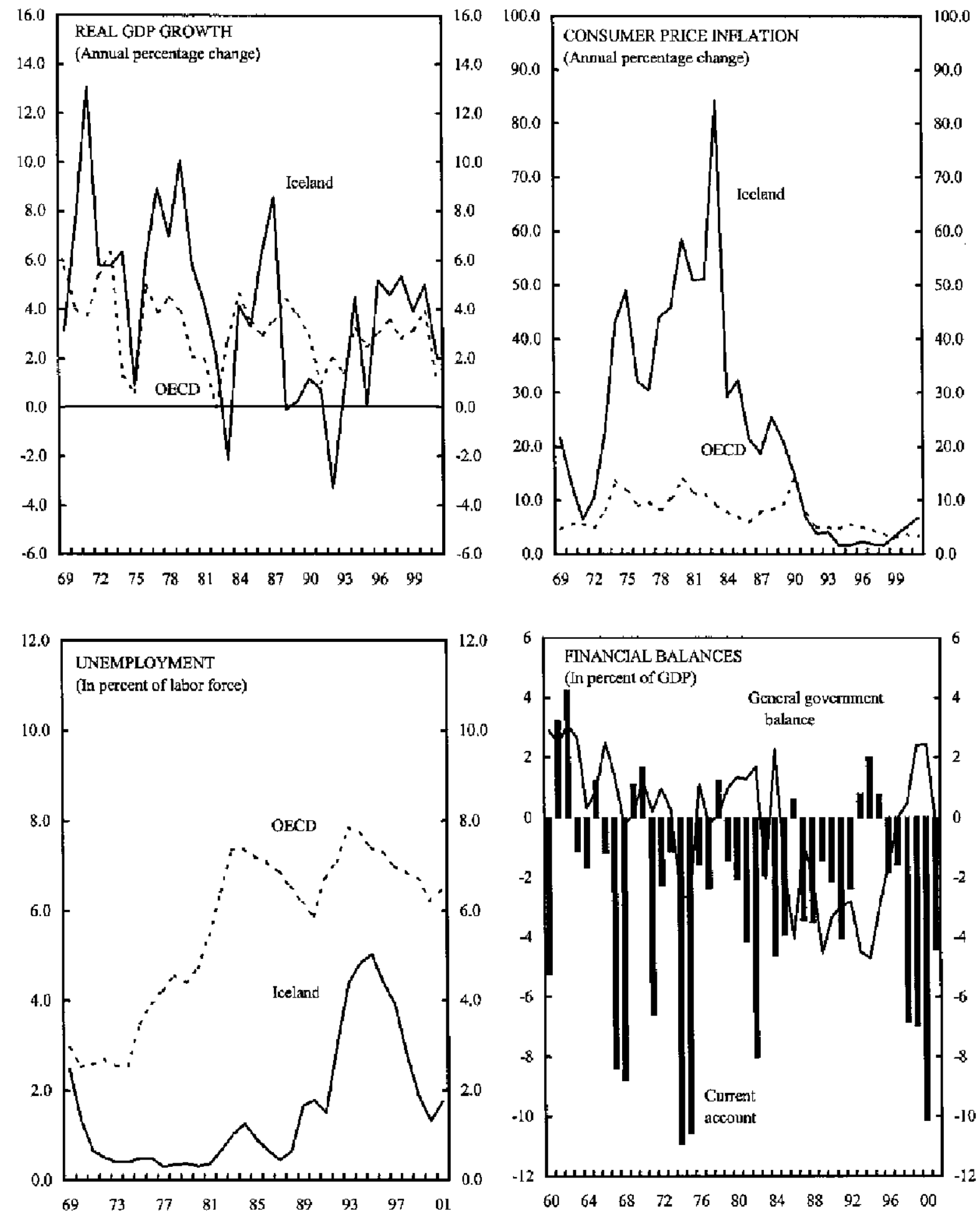

Sources: National Economic Institute: Central Bank of Iceland, and IMF, World Economic Outlook. 
Figure 3. Iceland: Income and Asset Prices
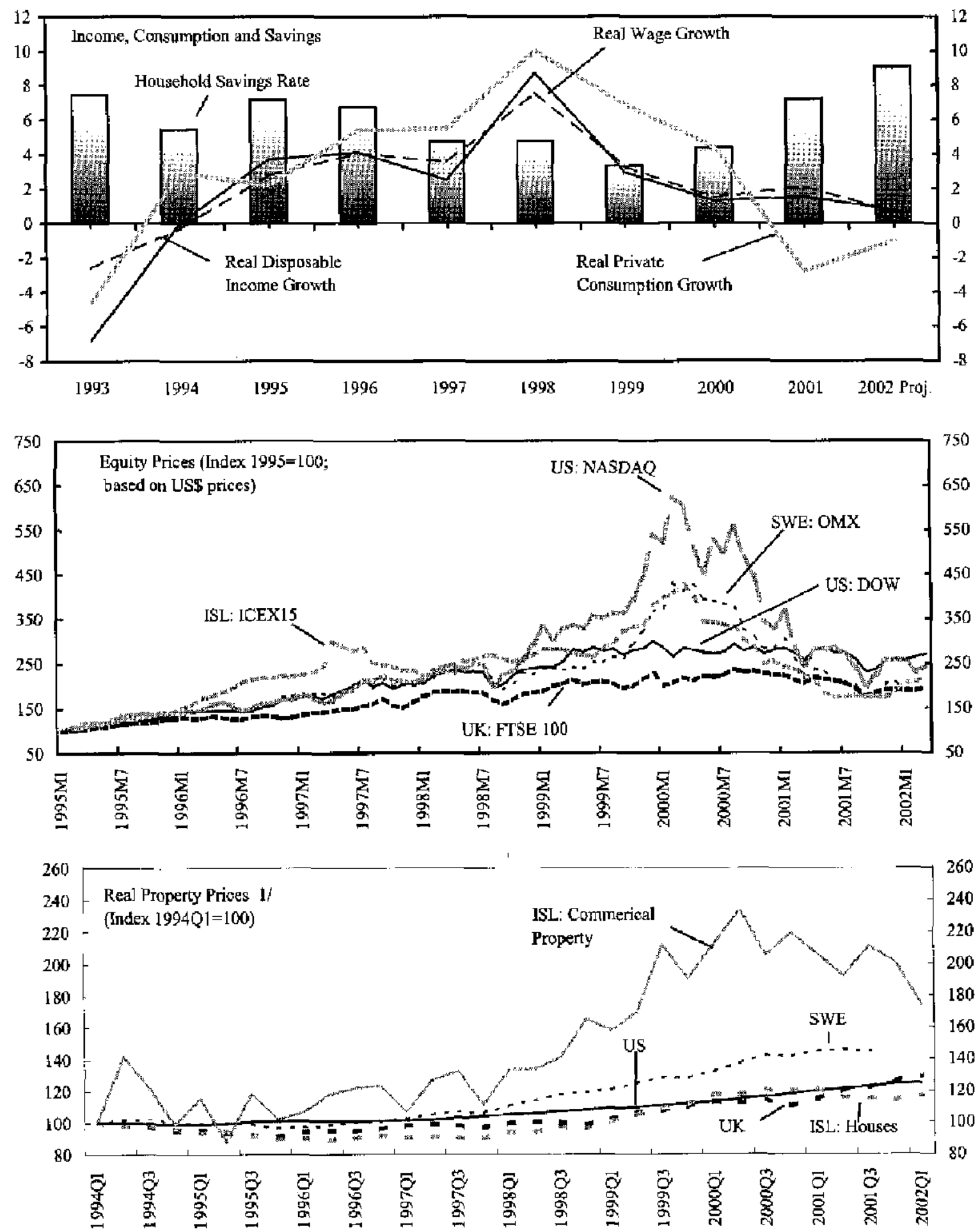

Sources: Central Bank of Iceland, National Economic Institute, Datastream, Bloomberg, and IMF staff estimates.

1/ For Sweden, the U.K. and the U.S. the figure reflects house prices only. 
Figure 4. Iceland: Saving, Investment, and Contribution to Growth
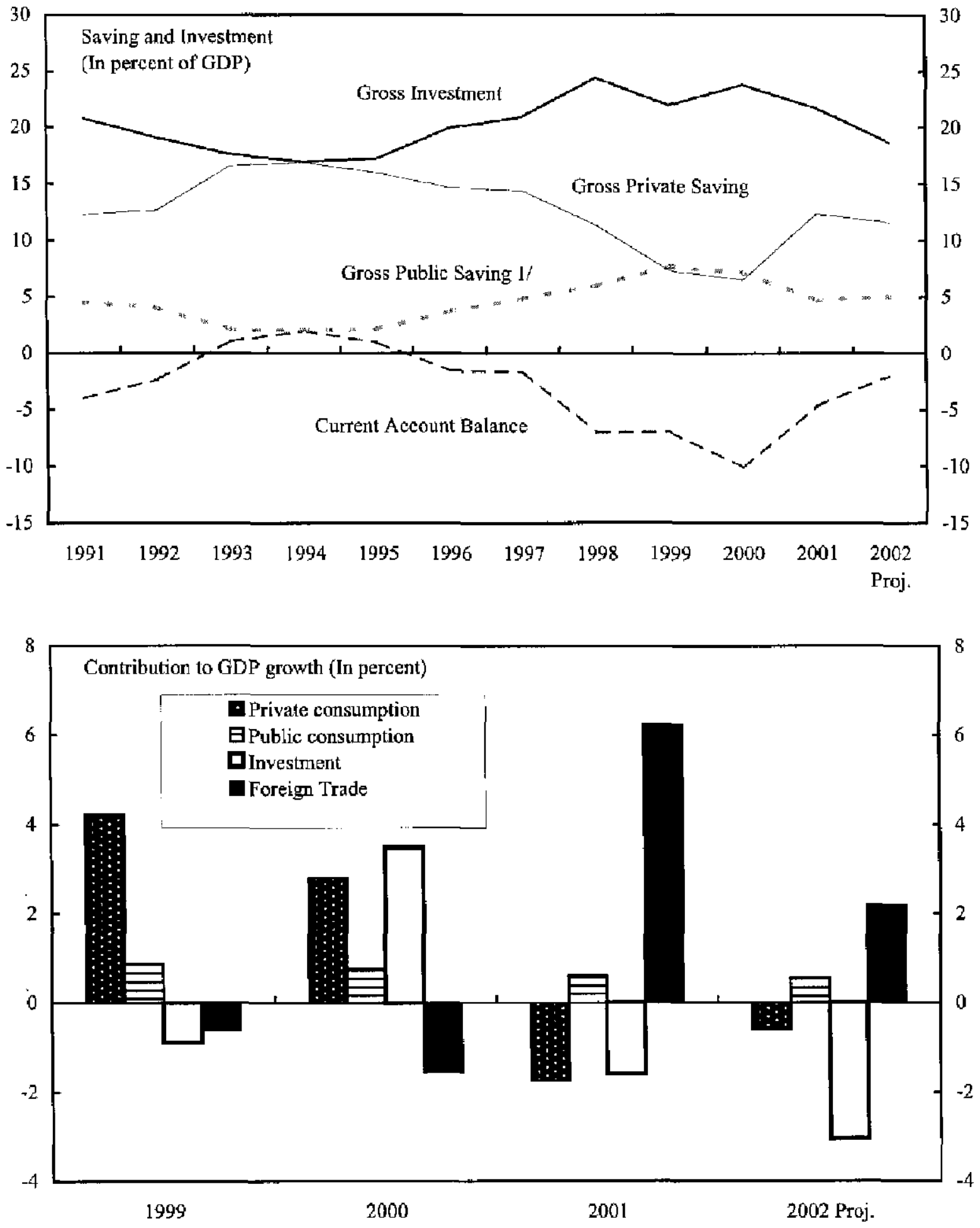

Sources: Central Bank of Iceland; National Economic Institute; IMF staff projections.

$1 /$ Includes revenues from privatizations. 
rate risk prompted by the adjustable peg system contributed to large capital inflows. ${ }^{1}$ The rapid expansion of bank lending-financed mainly by external borrowing for domestic onlending - raised banks' exposure to credit and market risks and weakened prudential indicators.

3. By mid-2000, the accumulated imbalances had come to the fore, prompting a sharp depreciation of the króna. Widening domestic and external imbalances caused a change in sentiment, triggered in Spring 2000 by negative news on the allowable fish catch, later compounded by the global slowdown and equity price declines. As capital inflows turned to outflows, the stock price index fell substantially and the króna experienced increasing downward pressure (Figure 5). On March 27, 2001, following several costly attempts to defend the exchange rate peg, the authorities announced the floating of the currency and the switch to an inflation-targeting framework. ${ }^{2}$ During 2001 , the overvaluation of the króna continued to unwind - possibly undershooting eventually its equilibrium value... despite occasional heavy interventions by the CBI. The króna stabilized at the end of the year and has recovered partially since then reflecting the evolution of demand and the external balance. $^{3}$

4. In the wake of the depreciation, a more sustainable balance between the internal and external sectors of the economy is being restored through a rapid redirection of activity towards exports, but inflation has been slow in abating. Real GDP growth decelerated from $5 \frac{1}{2}$ percent in 2000 to 3 percent in 2001 bringing it closer to its estimated long-term sustainable pace. More notably, the balance of demand switched swiftly from consumption and other domestic expenditure to net exports. Thanks to

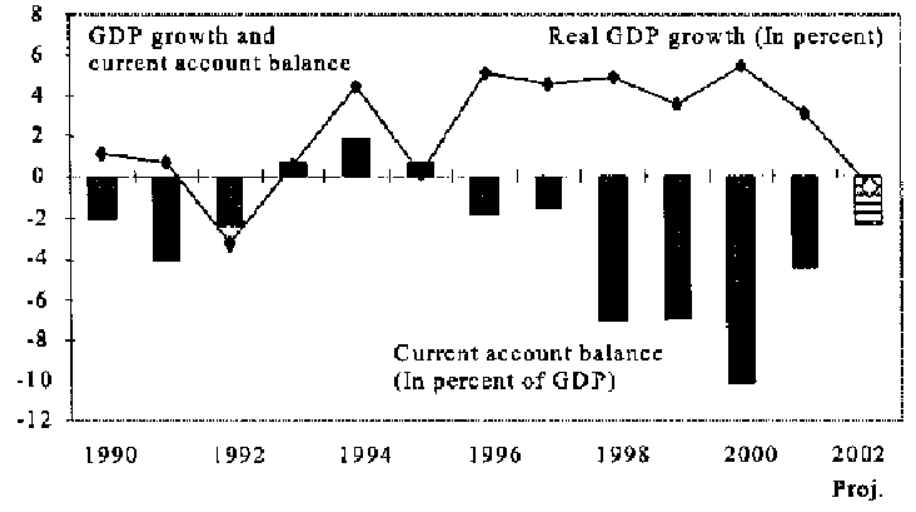

1 The króna had been pegged to a trace-weighted basket of currencies since 1989. Fluctuation bands were initially set at $\pm 21 / 4$ percent, but were subsequently widened to \pm 6 percent in September 1995 and to \pm 9 percent in February 2000.

${ }^{2}$ The inflation target is $2 \frac{1}{2}$ percent, to be achieved by end-2003. Upper tolerance limits were set at 6 percent until the end of 2001 and at $4 \frac{1}{2}$ percent during 2002; symmetric tolerance limits of $1 \frac{1}{2}$ percentage points around the target will take effect starting in 2003.

${ }^{3}$ For an analysis of current account sustainability and the exchange rate of the krona, see the Annex to the staff report for the 2001 Article IV consultation (IMF Country Report No. 01/81). 
Figure 5. Iceland: Exchange Rate and Competitiveness
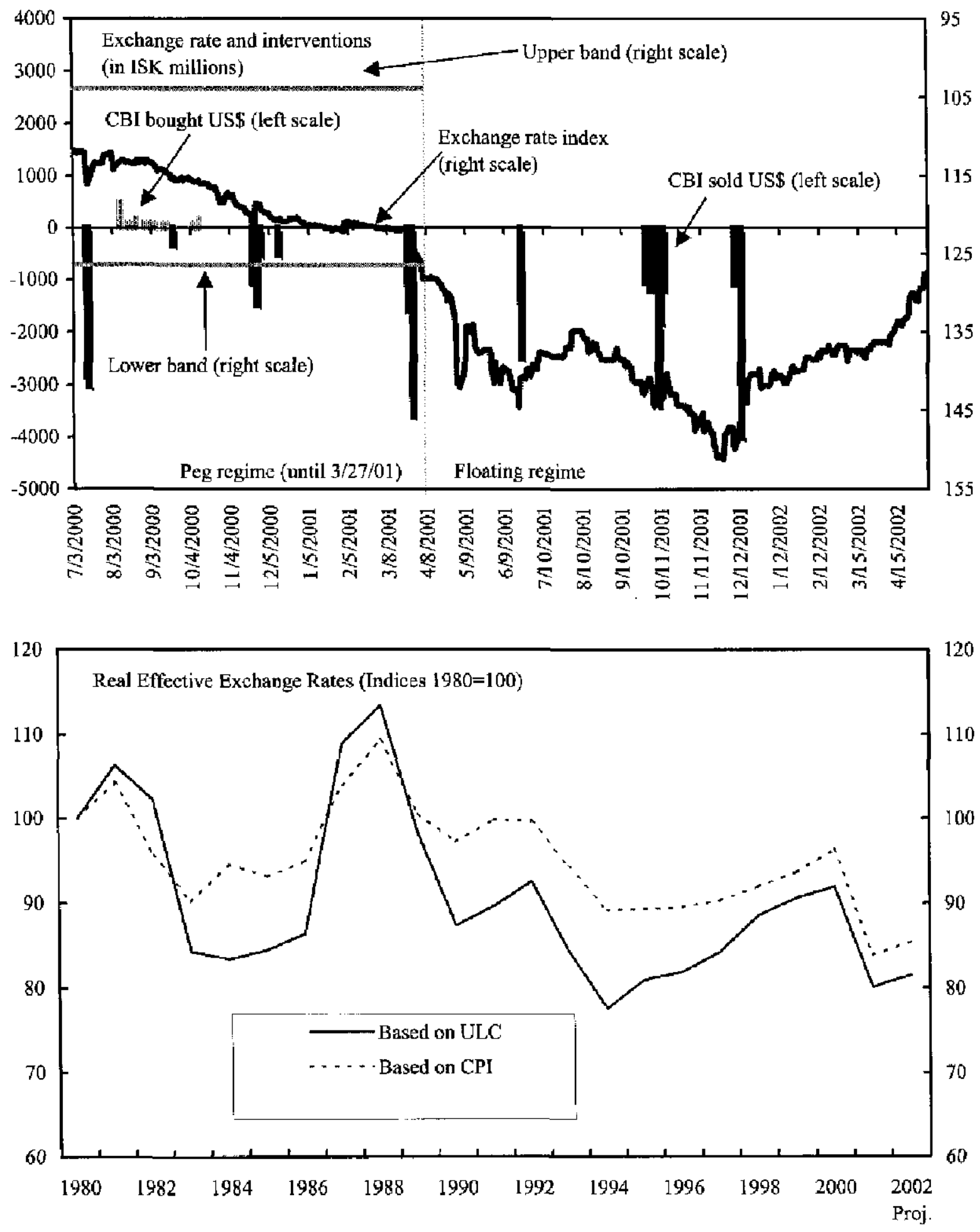

Sources: National Economic Institute; Central Bank of lceland; and IMF staff projections. 
both a sharp decline in imports and buoyant exports, the external current account deficit narrowed to about $4 \frac{1}{2}$ percent of GDP in 2001. At the same time, however, inflation rose rapidly and, despite a steep decline of the monthly inflation rate in 2002 , the twelve-month rate still stood at 5.9 percent in May 2002. The main cause of inflation has been the passthrough effect of the depreciation, but inflationary pressures have also been sustained by wage increases that have, on average, outpaced prices, and by a sizable fiscal impulse in 2001 resulting largely from overruns in public wages and other current spending.

\section{The baseline outlook is for a relatively soft landing in 2002 , with a further} correction of external imbalances and domestic consolidation, before growth resumes in 2003. The staff and the authorities concur in envisaging a further moderation in economic activity during 2002 with GDP declining year-on-year by $1 / 2$ percent. This would bring output only slightly below its estimated long-term trend. The redirection of activity toward the external sector is expected to continue as households and businesses, which have both accumulated high levels of indebtedness, consolidate their balance sheets. ${ }^{4}$ Domestic demand is projected to decline in 2002 by about 3 percent and the current account deficit to contract further, to 2 percent of GDP (Table 2 and Figure 6). CBI's analysis, partly based on market participant surveys, indicates adequate external financing of the current account (at constant exchange rates) -indeed, the króna has recently shown a tendency to appreciate, partly stemming from the turnaround in the trade balance since late 2001. The envisaged recovery in late-2002 is expected to be driven by the ongoing external demand push and a gradual pickup in domestic demand. Starting in 2003 and over the medium-term, the economy is expected to return to its trend pace of growth, underpinned by stronger fundamentals, while the current account further approaches balance in successive years (Table 3).

6. The risks to the baseline projection, however, are on the upside and tight policies will be needed to counter inflationary pressures and avoid a recurrence of earlier imbalances. The baseline projection is predicated on wage moderation and on continued adjustment in domestic savings and expenditure. But wage drift was strong in 2001 and has moderated only slightly in recent months as labor market tightness subsided (Figure 7). Stiil, at 2.2 percent in March 2002 (seasonally adjusted), unemployment was below most estimates of its natural rate and, despite the substantial decline in domestic demand, output remained possibly above its long-term trend. Under these conditions, public sector earnings growth and wage pressure in export-oriented industries could spill over to other sectors. Also, the drop in consumer sentiment-which played a crucial role in the adjustment-appears to be reversing as prices stabilize, incomes recover, and the króna appreciates. Newly released data showing surprisingly robust output growth in the last quarter of 2001 highlight these upside risks. Over the medium term, additional overheating strains could arise if some of the several large

\footnotetext{
${ }^{4}$ At end-2001, corporate indebtness was estimated at 130 percent of GDP and household indebtness represented 166 percent of disposable income.
} 
Figure 6. Iceland: Domestic and External Demand
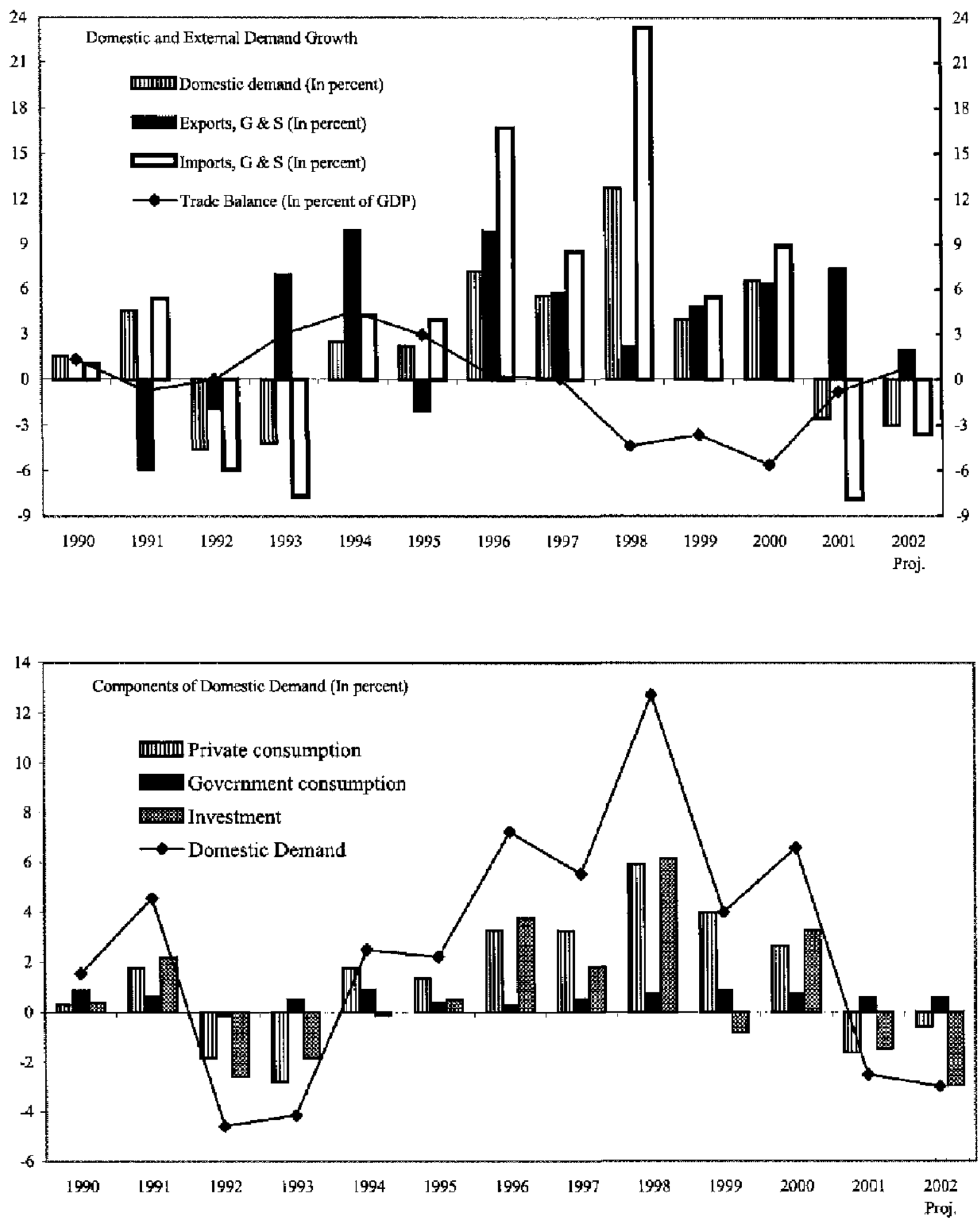

Sources: National Economic Institute and IMF staff projections. 
Figure 7. Iceland: Inflation and Wage Developments
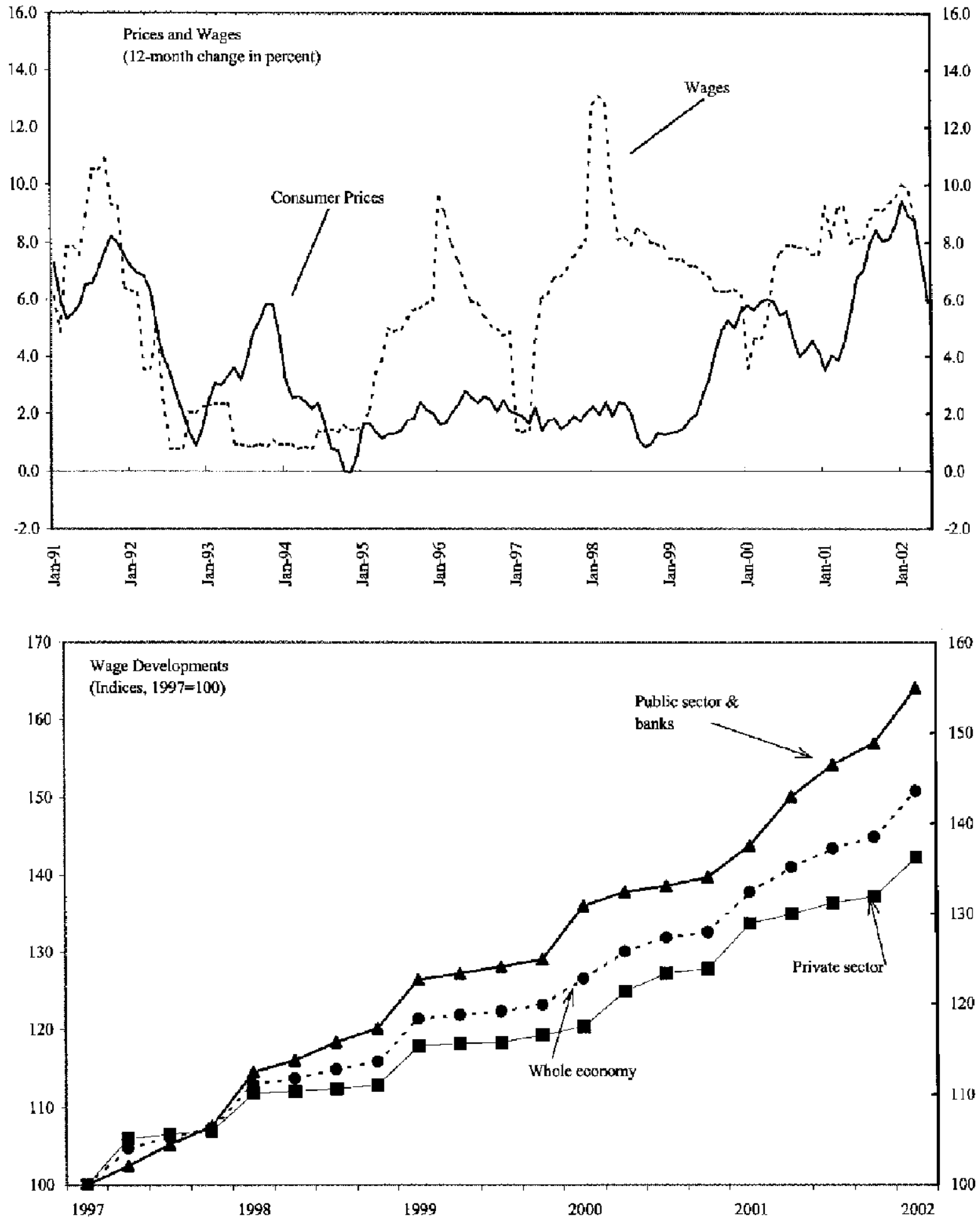

Source: Statistics Iceland. 
investment projects in energy generation and aluminum smelting (currently under discussion and not included in the central projections) should materialize.

\section{Policy Discussions}

7. The main focus of the discussions was the assessment, with MAE assistance, of progress in addressing the financial sector vulnerabilities reported in the 2001 FSSA and which had raised concern during the 2001 Article IV consultation. In this regard, staff was reasonably reassured by the situation of the banking sector and by the proactive approach of the authorities. Weaknesses, however, still remain and some time will be necessary to finalize and enact key legislation, currently under preparation. Staff was also encouraged by the rapid ongoing correction of economic imbalances, notably the significant reduction in the current account deficit. Still, prospects for an early resumption of sustainable growth hinge on consolidating price and exchange rate stability. Developments in this area, including since the discussions took place, have been favorable. But a tight monetary stance will still be necessary for some time to anchor inflation expectations and prevent a recurrence of past imbalances. From a longer-term perspective, maintaining the soundness of the public finances and continuing progress on structural reforms will be crucial to sustain the growth and diversification of the Icelandic economy while minimizing the volatility of output and vulnerability to external shocks.

\section{A. Financial Sector Policies}

8. During 2001, the banking system improved profitability and bolstered its capital adequacy position, notwithstanding significant stresses stemming from securities markets, the devaluation of the króna, and the deceleration of economic activity (see Annex). Commercial banks' profits increased in 2001, helped by widened interest rate margins, cost efficiencies, and the favorable net effects of inflation on banks' balance sheets. In comparison, savings banks reported less favorable results, as they suffered greater loan losses and were slower in rationalizing costs. Non-performing loans and corresponding provisions increased substantially in 2001 reflecting the downturn in domestic demand on the consumer, retail, and other non-exporting sectors - staff noted, however, that the level of provisioning remained relatively low. Contrary to prior concerns, banks reported that foreigncurrency denominated loans had continued to perform well, despite the depreciation of the króna, owing to the stricter lending criteria applied to these loans and to buoyant revenues in the export-oriented sectors of the economy. Banks expanded their regulatory capital base through subordinated debt issuance, strategic acquisitions financed with new shares, and retained earnings. As a whole, the banking system increased the regulatory capital ratio from 9.9 percent in 2000 to 11.5 percent in 2001 (Tables 4 and 5).

9. The authorities have made progress in addressing weaknesses of the prudential, regulatory and supervisory system identified by the 2001 FSSA report and have agreed 
to a FSSA follow-up in 2003. ${ }^{5}$ The Financial Supervisory Authority (FSA) has followed a proactive approach to supervision and strengthened financial regulations and supervisory resources. The authorities' efforts were instrumental in bringing about management changes in some banks, improving management practices of financial institutions, and encouraging banks to raise their capital. These efforts have resulted in improvements in macro- and microprudential indicators of financial vulnerability (Tables 4 and 5). The authorities are preparing an ambitious legislative package on banking, securities, and financial markets regulation to be introduced in Parliament in the Fall of 2002, which will substantially expand the regulatory mandate of the FSA, including to non-bank financial activities. The legislation will provide for the prescription of additional capital requirements for banks according to their individual risk profiles. This is of particular importance given that the small size of the Icelandic economy entails in some cases an unusual concentration of exposures. It will also allow integrated supervision of increasingly linked financial activities and consolidated supervision of connected groups. In supporting these reform steps, staff encouraged the authorities to accord high priority to prompt enactment of this legislation.

\section{Against the background of the steps already taken, discussions focused on} remaining financial sector vulnerabilities and additional improvements to the prudential framework. Staff saw room for further approaching best international practices by tightening minimum standards for loan classification, provisioning, and collateral valuation. Loan portfolio credit quality is expected to deteriorate again in 2002 reflecting the decline in economic activity and stricter loan classification rules recently introduced. Thus, timely monitoring of collateral values and associated provisions will be necessary. Staff also recommended more comprehensive on-site examinations and emphasized the need for enhanced monitoring of growing securities lending and investment banking operations. The authorities considered the staff's suggestions to be broadly in line with their own plans and indicated their intention to maintain under review all newly introduced prudential standards, with a view to tightening them if necessary. Beyond the banking sector, the authorities concurred that securities lending by pension funds-an incipient development partly prompted by demand for eligible securities for discount in the CBI's repo facility-might generate unmonitored credit risk exposures and conflicts of interest, thus requiring specific supervisory attention.

\section{B. Monetary Policy}

11. During 2001, the steep depreciation of the krona and the attendant inflationary spike complicated the management of monetary policy and the consolidation of the new inflation-targeting regime. The króna depreciated by about 30 percent in nominal effective terms during January-November 2001, and the policy target inflation rate (the 12-month rate)

\footnotetext{
${ }^{5}$ See "Iceland: Financial System Stability Assessment," IMF Country Report No. 01/85, June 2001.
} 
rose rapidly, reaching 9.4 percent at its peak in January 2002 -both repeatedly exceeding market expectations. The CBI cut rates twice in 2001 in the midst of intense political pressure: first, in March 2001 at the time of introduction of the new inflation-targeting regime, and again in November 2001 (by a total of 130 basis points to 10.1 percent)-despite ongoing inflation above the tolerance range--mainly on the perception that its monetary stance had tightened in real terms owing to a decline in inflation expectations (Figure 8). Inflation developments and inflation expectations, however, proved difficult to gauge and the short-term end of the CBI's inflation forecast (made under the assumption of a stable exchange rate) was often overtaken by events-while occasional sterilized interventions in the foreign exchange market failed to contain the depreciation of the króna. As a result, the policy stance was loose and confidence weak. In retrospect, the actual real interest rate of the CBI's two-week repo facility averaged $1 / 2$ percent during March-December 2001, becoming negative for several months. In this setting, inflation expectations remained high ( $61 / 2$ percent in the January 2002 public survey).

\section{At the time of the discussions, evidence was starting to emerge of favorable price} and exchange rate developments entailing a tightening of monetary conditions and since then the CBI has cut the policy rate to 8.8 percent. The authorities noted that, rooted in the contraction of domestic demand and the rapid turnaround in the trade balance, price and exchange rate developments had moved in a positive direction-a trend confirmed by events since the discussions took place. By mid-May 2002, the króna had appreciated by about 15 percent since its low in November, the month-onmonth (seasonally adjusted) inflation rate was negative after declining sharply for five consecutive months, and

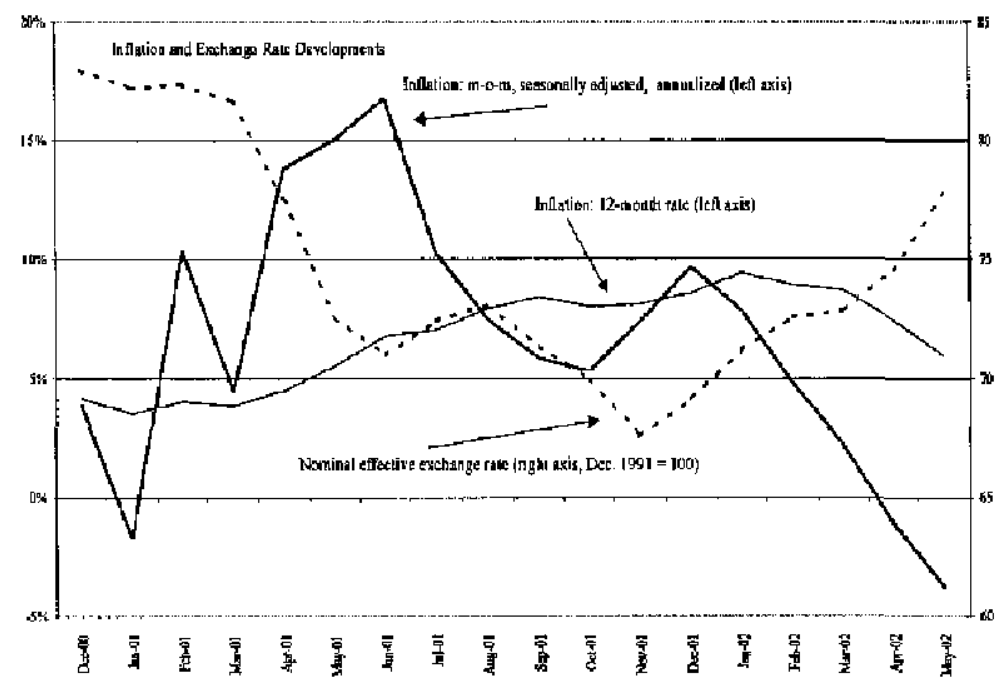
banking sector lending (adjusted for the automatic indexation of principal) bad virtually come to a halt. Also by mid-May 2002, labor market tightness was easing and the May 2002 ceiling on inflation that, if exceeded, could have triggered a renegotiation of wage settlements, had been met (Figure 9). ${ }^{6}$ As indications of these developments emerged, the $\mathrm{CBI}$ cut rates on

${ }^{6}$ The labor unions agreed in December 2001 to postpone the review of labor contracts to May 2002 and increase the threshold rate of inflation that would trigger a revision of wages from 3 percent to 6.3 percent. 
Figure 8. Iceland: Interest Rate Developments
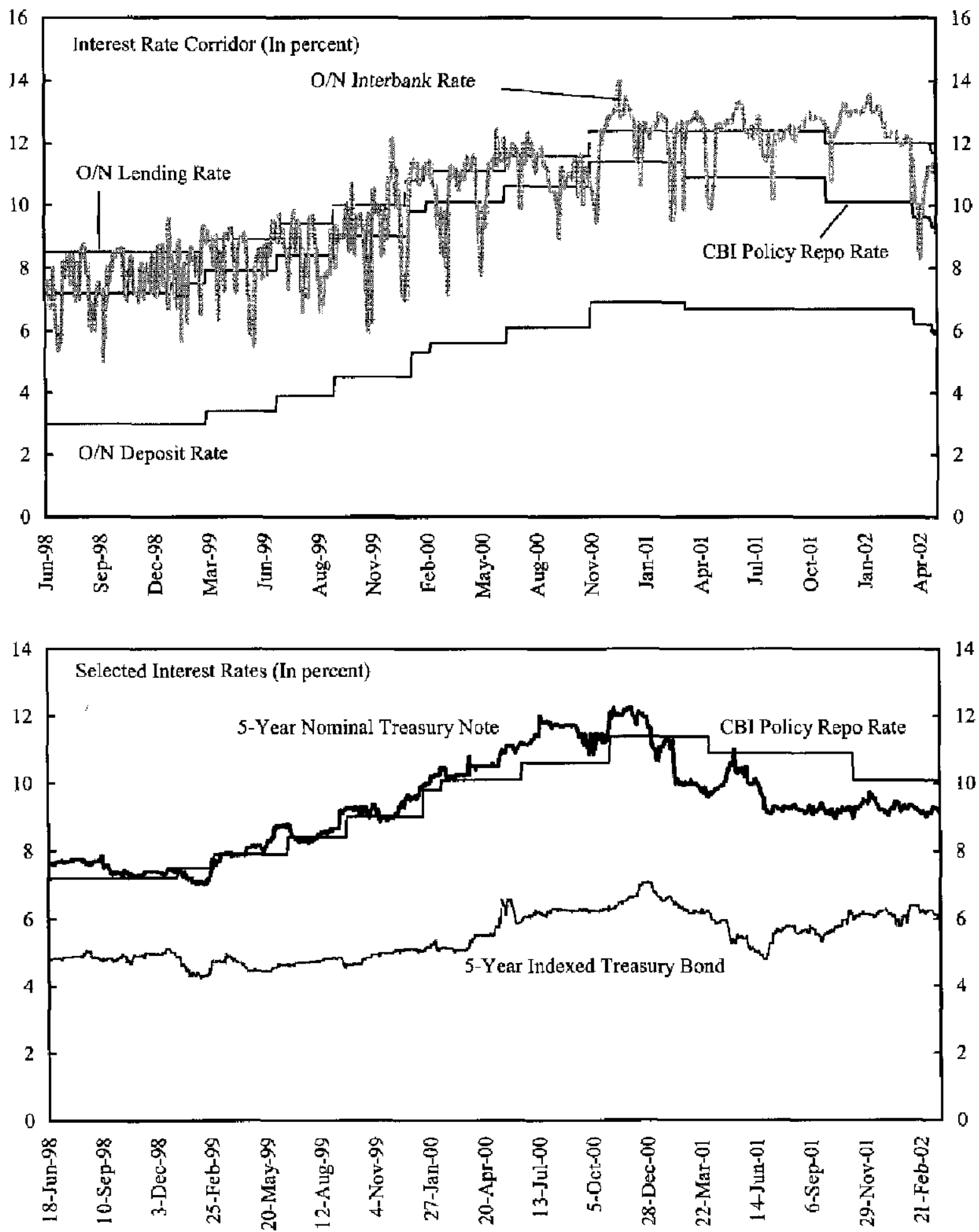

Source: Central Bank of Iceland. 
Figure 9. Iceland: Money, Credit and Liquidity Operations
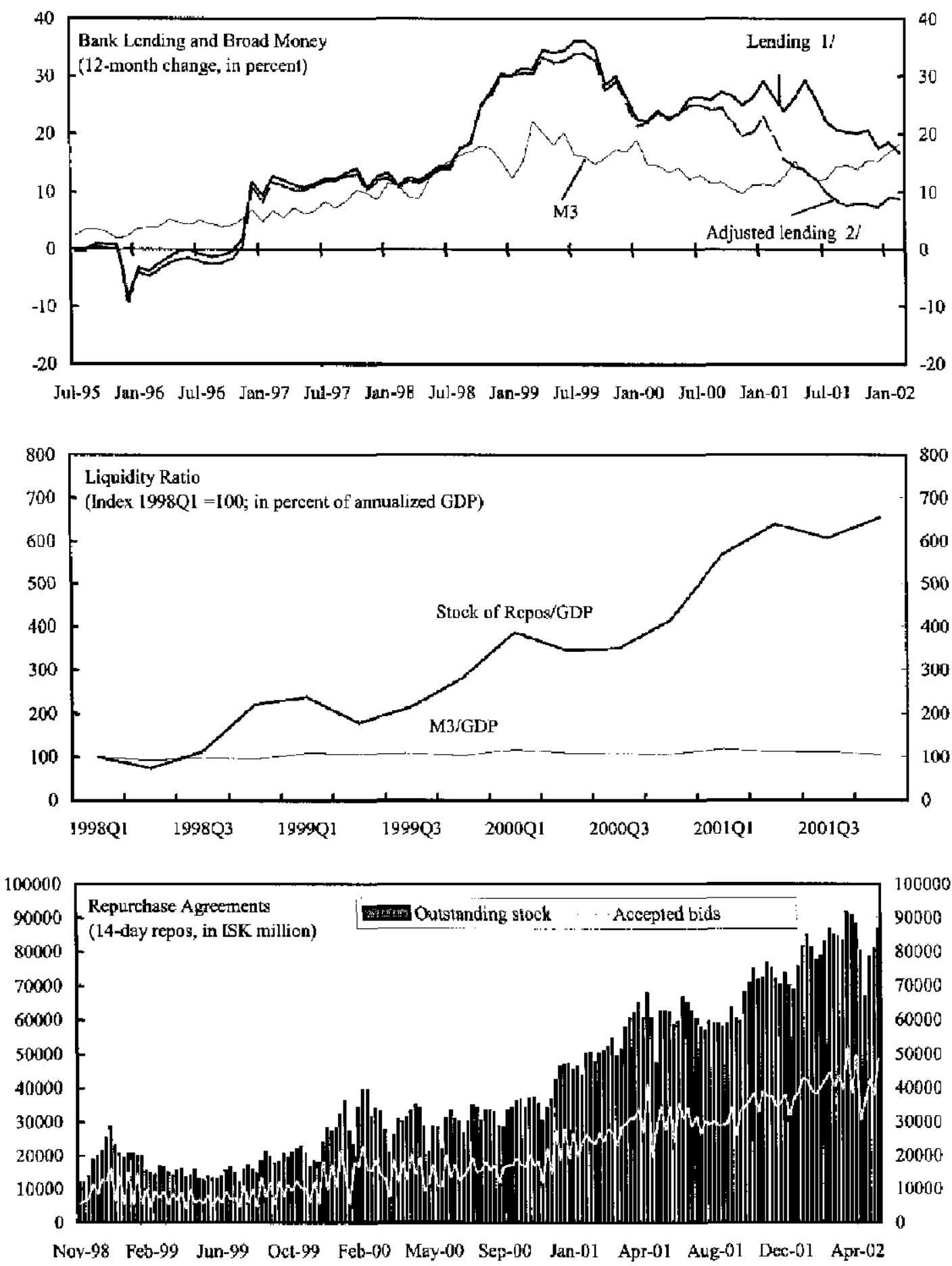

Source: Central Bank of Iceland.

1/ From March 1999, 12-month changes include lending by FBA investment bank. By way of its merger with commercial bank Íslandsbanki, FBA entered the DMB data set in June 2000. 2/ Adjusted for exchange rate and inflation effects on the principal of indexed loans. 
several occasions during the March-May period and the May 2002 CBI Monetary Bulletin revised downwards the inflation forecast. This forecast now envisages that the 12 -month inflation rate will be within the tolerance range (below $4 \frac{1}{2}$ percent) by the third quarter of 2002 and will reach the $2 \frac{1}{2}$ percent target before the end of 2003 .

13. Staff cautioned against a premature easing of the policy stance and stressed the need to cement the monetary policy framework and anchor inflation expectationssince the situation remained volatile with significant upside risks for inflation. The authorities noted that as inflation expectations declined and the króna strengthened, an unchanged nominal interest rate implied an increasingly tighter real policy stance, allowing for policy rate cuts. While agreeing with the thrust of the authorities' analysis, the mission argued for a cautious assessment of the situation - not least, to nurture the credibility of the inflation-targeting regime - as it was still early to ascertain the role played by one-time factors and special measures which would not affect long-term inflationary developments. ${ }^{7}$ In the staff's view there remained significant risks to the inflation outlook including (i) the delayed pass-through effects of the 2001 exchange rate depreciation (see Box); (ii) wage drift and high inflation expectations that could impinge on wage setting and pricing behavior; (iii) the upside risks to the growth projections, as discussed above; and (iv) robust growth of monetary aggregates.

\section{Looking forward, discussions centered on the need to keep a tight monetary} stance that is firmly focused on the CBI's price stability mandate and on achieving the authorities' inflation target by end-2003. Recent developments, including after the discussions took place, and the May 2002 CBI inflation forecast support the current policy stance. Also, there was agreement that, if ongoing inflation developments confirmed the envisaged price path, there would be room for further interest rate cuts. But staff advised pacing policy moves with evidence that inflation would remain low, while maintaining close consistency with the official CBI inflation forecast as required by inflation targeting. Thus, the authorities should not hesitate to act symmetrically, delaying interest rate cuts or reversing them if warranted. Specifically, in the context of the global economic recovery, a possible rebound in earnings, and strengthening consumer confidence, the authorities will need to be vigilant to early signs of faster-than-envisaged consumption and credit growth that could reignite inflation pressures and threaten the resumption of a sustainable growth path in 2003.

\footnotetext{
7 These included the borrowing abroad in October 2001 of ISK 25 billion ( $31 / 2$ percent of GDP) by the government to replenish the reserves of the CBI; repatriation of assets by pension funds; and tax, tariff, and administered price measures taken to limit price increases.

${ }^{8}$ The dynamic effects of the exchange rate, wages, and other factors on inflation are discussed in Chapter 1 of the accompanying Selected Issues Papers.
} 


\section{Box. Exchange Rate Pass-Through and Monetary Policy Transmission Mechanism}

The pass-through of exchange rate shocks has a significant impact on domestic inflation in small open economies like Iceland. Staff estimates suggest a sizeable impact coefficient, i.e. some 15-20 percent of an exchange rate shock finds its way into domestic prices within one quarter. The pass-through coefficient peaks at about 0.35 after roughly six months and then gradually levels off over a period of approximately 18 months. ${ }^{1}$ Stylized facts of inflation developments in Iceland appear to confirm these findings. The sharp increase in monthly inflation in Fall 2000 and mid2001 was mainly fueled by higher import prices responding swiftly to the depreciation of the króna; prices of domestic goods and services rose with a time lag of about 3 months. Since mid-2001, domestic goods prices appear to have reacted more swiftly to exchange rate variations suggesting a slightly stronger pass-through-possibly because of diminished margins among producers following the prolonged depreciation of the króna which started in Spring 2000 . Conversely, the most recent decline in inflation was driven by the appreciation of the króna since end-2001 resulting in a decline in import price inflation mitigated in part by a lagged response of services prices.

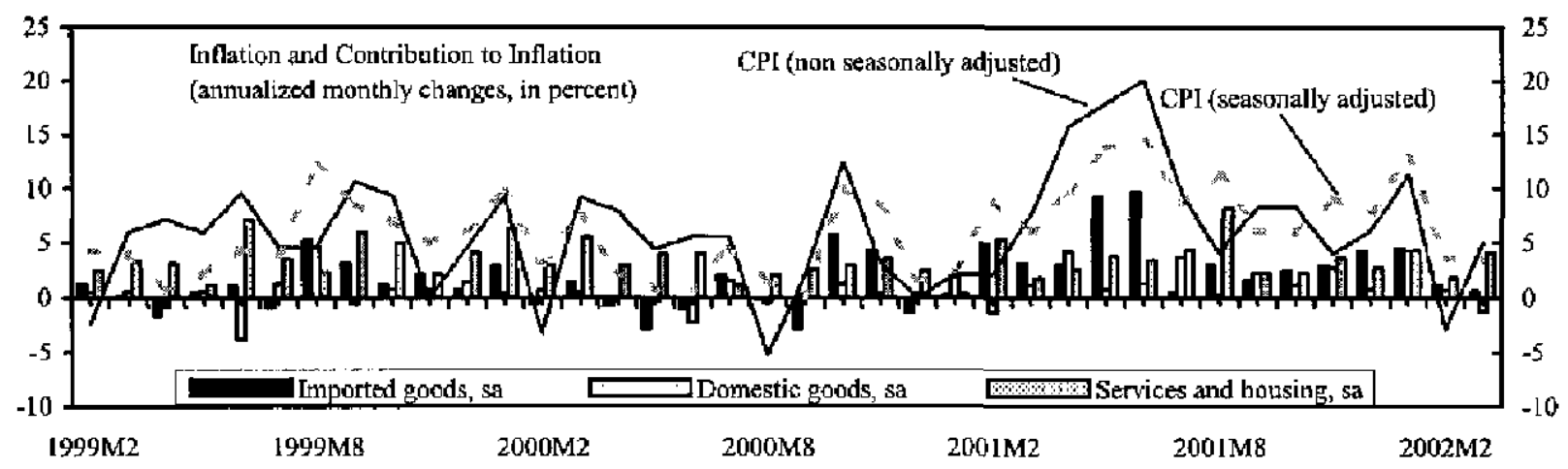

Experiences of open cconomies with inflation-targeting regimes indicate that exchange rate shocks are large but predominantly of a short-term nature, calling for monetary policy to focus on a medium-term inflation forecast. ${ }^{2}$ Recent empirical work by Pétursson (The Transmission Mechanism of Monetary Policy: Analyzing the financial market passthrough, CBI Working Paper No. 14, November 2001) suggests that monetary policy lags are somewhat shorter in Iceland than in other industrial countries, owing to the weight of the exchange rate channel and the country's openness. Interest rate changes are transmitted swiftly throughout the yield curve with the 5-year government bond yield and the repo rate as the main determinants of banks' marginal cost of lending. Further research by Pétursson (The Transmission Mechanism of Monetary Policy, CBI Monetary Bulletin, November 2001) indicates that significant effects on prices occur after one year, reaching a peak after about $1 \frac{1}{2}$ year with the annual rate of inflation falling by 0.35 percentage points in response to a 1 percent rise in the policy rate.

${ }^{1}$ See Chapter I of the accompanying Selected Issues Papers. This finding is consistent with CBI empirical work (Pétursson (2002), Wage and Price Formation in a Small Open Economy, CBI Working Paper No. 16).

${ }^{2}$ See, for instance, Mihaljek and Klau (2001), A note on the pass-through, BIS Paper No.8 (part 3) and IMF Country Report No. 01/82.

\section{Discussions also covered possible enhancements of the monetary policy}

framework and operational procedures. In this connection, staff emphasized that the recently accorded Central Bank operational independence necessitates that the CBI be free to focus on its price stability mandate and set its monetary policy stance accordingly, unencumbered by outside pressures. Also, to buttress the transparency, predictability, and 
public understanding of monetary policy, staff suggested that the authorities consider establishing rate-setting meetings of the CBI Board of Governors at regular dates, publishing subsequently a detailed statement containing the analysis and considerations that led to the adopted policy decision. The authorities indicated that, while maintaining the options suggested by the staff under review, they had decided to keep the flexibility afforded by current arrangements. They considered that, at this stage, notes announcing rate moves and the quarterly CBI Monetary Bulletin, with extensive analyses and inflation projections, provided sufficient background to policy decisions.

\section{Regarding liquidity operations and money markets, staff expressed concern} about the rapid growth of CBI lending through its repo facility and discussed reforms in these areas. Outstanding repos reached ISK 92 billion in March 2002 (about 12 percent of projected annual GDP) and could be replacing regular sources of bank financing, discouraging interbank lending, and distorting money markets. Staff suggested that the authorities consider reforming the repo facility to foster the development of the interbank market and improve liquidity management. The authorities explained that the main cause of the high level of outstanding repos had been the sterilization of the forex market interventions undertaken by the CBI in 2000-01. They shared some of the staff's concerns and were analyzing potential imperfections in the money market and researching the design of liquidity operations in other Nordic and inflation-targeting countries, with a view to improving the CBI facilities if necessary. In a separate development, the authorities have introduced a foreign-currency swap market to allow collateralized liquidity borrowing among banks and large market participants, and smooth out volatility in the spot forex market. Staff suggested consideration of gradually allowing banks to maintain required reserves with the CBI against foreign-currency denominated liabilities in matching currencies, in order to minimize oscillations in the demand for liquidity.

\section{Fiscal Policy}

17. Owing to fiscal consolidation and public-debt reduction, the public finances are sound, and the authorities aim at a moderate budget surplus over the medium term (Table 6 and Figure 10). Strong revenue performance and privatization proceeds in recent years allowed the partial capitalization of public pension obligations as well as a reduction in net government debt to 28 percent of GDP at end-2001. ${ }^{9}$ The authorities considered the 2000-01 deterioration in the fiscal balance as temporary and aim to achieve a budgetary surplus of about 1 percent of GDP over the medium term. They also indicated that privatization proceeds would continue to be devoted mainly to reducing the net government debt. The authorities aim at a continued decline in government liabilities, including a further

${ }^{9}$ Gross government debt was 47 percent of GDP at end-2001. 
Figure 10. Iceland: Fiscal Developments
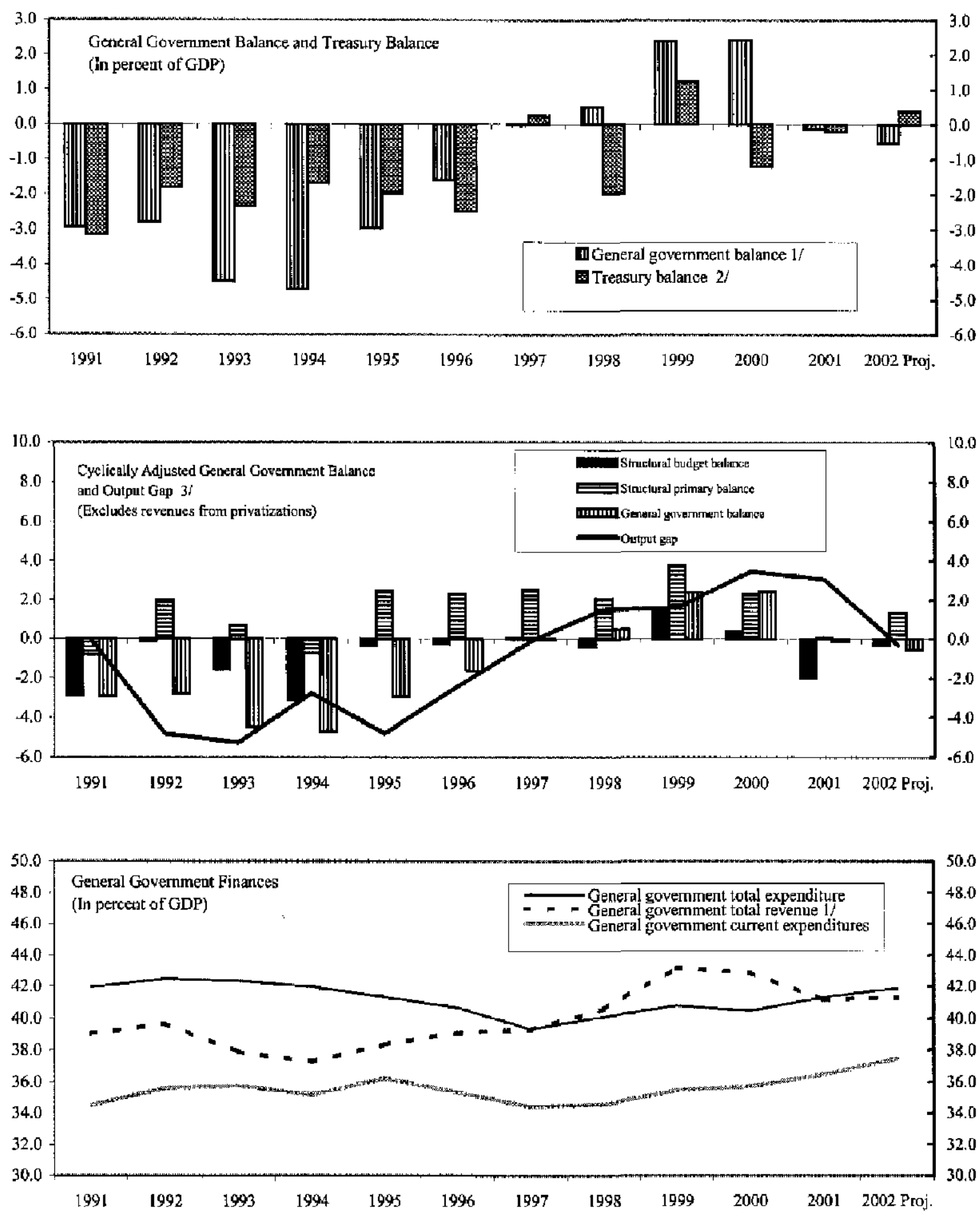

Sources: National Economic Institute; Ministry of Finance; and IMF staff projections.

1/ Accrual basis; including imputed government pension liabilities. Excludes revenues from privatization. 2/ Cash basis until 1998. From 1999 onwards on accruals basis. Excludes revenues from privatization.

3/ Actual output minus potential output, in percent of potential GDP. 
gradual reduction of external debt over the medium term. Staff agreed that a moderate cyclicaily-adjusted surplus and further debt reductions were appropriate objectives in light of the need to create a buffer against external shocks and increase national savings.

\section{After under-performing in 2001, the 2002 budget envisages a contractionary} stance-although expenditure consolidation will affect the capital budget rather than recurrent spending. The 2001 budget outturn indicates that a loosening of the fiscal stance took place, rather than the moderate tightening originally planned. In particular, appropriations had to be increased owing to high wage settlements (mainly in the health and education sectors), and retroactive disability payments following a Supreme Court ruling. The general government deficit in 2002 is projected at $1 / 2$ percent of GDP, slightly higher than the deficit outturn in 2001 . Still, on a cyclically-adjusted basis, the 2002 budget represents a fiscal retrenchment of about 1.7 percentage points of GDP, stemming largely from the completion and scaling down of several large investment projects. Staff concurred that this was necessary to correct for the overspending of recent years and initiate a return toward the intended medium-term fiscal path. But it expressed concern that the envisaged fiscal consolidation in 2002 relied mostly on capital spending cuts, which could undermine the authorities' policy of improving infrastructure and productivity. Further, the growth of recurrent expenditure at the expense of the capital budget was not a sustainable policy. Instead, a successful medium-term strategy of fiscal consolidation needed to tackle the increase of current spending, as the experience of other OECD countries demonstrated ${ }^{10}{ }^{10}$ The authorities agreed with the thrust of the staff's views and indicated that multi-year pay agreements and other settlements - the main cause of past spending overruns-had been concluded in 2001, which would facilitate containing current spending in coming years. Also, the authorities had tightened operational procedures for budget implementation with a view to improving expenditure control.

\section{The discussions reviewed reforms to the fiscal framework that would strengthen} bndgetary discipline and improve the transparency and predictability of fiscal policy. In particular, staff noted that the medium-term orientation of fiscal policy could be enhanced by introducing muiti-year budget plans with explicit expenditure limits and cyclically-adjusted balance objectives. Although these features are currently present to some extent in the budget formulation process, they are not an integral part of the fiscal framework. Furthermore, the link between medium-term macroeconomic policies and budget discussions would be strengthened by expanding the coverage of budget projections and reports to all levels of the general government, including local authorities; and adopting accounting methodologies consistent with the national accounts system. The authorities were considering possible

\footnotetext{
${ }^{10}$ See, for example, Alesina and Perotti: "Fiscal Expansions and Adjustments in OECD Countries" (Economic Policy, Vol. 21, 1995) and Alesina and Perotti: "Fiscal Adjustments in OECD Countries: Composition and Macroeconomic Effects," (IMF Staff Papers, Vol. 44, No. 2, 1997).
} 
reforms broadly along the lines suggested by the staff, although substantive changes to the fiscal policy framework were not envisaged in the immediate future.

\section{Structural Reforms}

20. The tax reform introduced in 2002 will streamline the taxation of income, particularly from savings and investment, and align the Icelandic tax system more closely to that of other industrial countries; also, a levy on fishing rìghts has been introduced in Parliament. ${ }^{11}$ The authorities pointed to the threefold objective of the recent reform of income taxes: simplifying the tax system, encouraging saving, and improving efficiency by reducing distortions across different economic activities. The reform is to be phased in during 2002-03 and includes the elimination of inflation-adjusted corporate accounting, the repeal or reduction of various additional corporate and personal wealth taxes (wealth tax, net wealth tax, and special wealth tax), and a cut in the corporate tax rate from 30 to 18 percent. The revenue loss from the tax changes (excluding dynamic supply effects) is estimated at an annual average of about 0.4 percent of GDP over 2002-03. The new levy on fishing quotas will tap the economic rents generated by the exploitation of the national fishing resources. Its base is defined presumptively on the basis of a notional average operational profit of the industry for the year-thus, it avoids penalizing fishing companies with higher value added and efficiency in the use of resources. The Govermment removed tariffs on most imported agricultural products in March 2002, replacing them with direct subsidies to domestic farmers, aiming to reduce consumer prices and remove price distortions. Although this measure is a positive step in improving efficiency, the level of farming subsidies is high and the staff encouraged the authorities to develop a strategy to curtail protection in this sector.

\section{Having established a solid track record of market-oriented structural reforms,} the authorities planned to press ahead with their reform agenda, which could be usefully expanded to new areas. The privatization process suffered a temporary delay in 2001 owing to market conditions and difficulties in finding strategic investors for the telecommunications company and two publicly-owned banks. Currently, privatization of the remaining controlling public stake in these companies is envisaged to start in 2002. The authorities are also preparing a comprehensive restructuring of the electricity generation, transmission, and distribution sectors and their legislative and regulatory frameworks, with a view to enhancing market incentives and align practices with those of the EU. Staff encouraged the authorities to consider widening the scope for private sector provisioning of services that are currently within the public sphere, including in the areas of health care and education. Initiatives in this direction could improve efficiency in the provision of these services while reducing strains on the budget. Staff also suggested increasing the flexibility of the wage bargaining process, allowing for wider variation in wage increases that better reflect

${ }^{11}$ The tax reform is analyzed in Chapter 2 of the accompanying Selected Issues Papers. 
productivity differentials across sectors and fims-thus facilitating the redeployment and efficient use of resources.

\section{E. Other Issues}

22. Iceland has a well-developed and comprehensive system to combat money laundering and the financing of terrorism. Iceland is one of the pilot countries that completed the Fund's Anti-Money Laundering/Combating the Financing of Terrorism (AML/CFT) questionnaire. The authorities explained that the anti-money laundering framework includes provisions on customer identification, the reporting of unusual transactions, regulations to seize assets, and staff training requirements on financial institutions. Additional CFT legislation to implement recent U.N. guidelines is currently in Parliament. The FATF considers that the Icelandic anti-money laundering system meets most of the essential requirements of its Forty Recommendations. Iceland is also a member of the Egmont group of financial intelligence units.

23. The OECD considers that Icelandic legislation conforms to the standards of the Anti-Bribery Convention. Iceland ratified the Convention in August 1998 and enabling legislation was enacted in April 2000.

24. Iceland has increased its budgetary allocation for Official Development Assistance (ODA) in real terms. In 2002, ODA spending is estimated at 0.13 percent of GNP. The authorities have expressed agreement with providing duty-free access to the least developed countries and Iceland has unilaterally granted tariff concessions to these countries similar to those that apply to European Economic Area members.

\section{STAFF APPRAISAL}

25. The growth of the Icelandic economy over the last decade has been remarkable. This dynamic performance has been largely the result of the authorities' policies consistently aiming to enhance competitiveness and diversification of the economy. The price and exchange rate stability gained in the early-1990s was followed by sustained fiscal consolidation efforts and market-oriented structural reforms that promoted investment and growth, including financial and capital account liberalization in the context of Iceland's membership in the European Economic Area. More recently, the introduction of a floating exchange rate regime and of an inflation-targeting framework are welcome steps suited to the characteristics of the Icelandic economy.

26. Much progress has been accomplished in redressing the imbalances that developed during the 1998-2000 period of economic overheating and the outlook is for a relatively soft landing of the economy. Output growth is slowing toward its long-term trend and the large 2000 current account deficit has been more than halved in 2001. The prospects are for a modest decline in output during 2002 as a further contraction of domestic demand is partly offset by the ongoing expansion of net exports. Growth is expected to 
resume in late 2002 driven by external demand and a gradual recovery in domestic spending. Upward risks, however, remain and tight policies will be necessary to prevent a rekindling of earlier imbalances.

\section{The situation of the banking sector has improved in 2001 and the prudential} supervisory framework has been strengthened - though some weaknesses remain. The progress made by the authorities in addressing the issues raised in the 2001 FSSA and the decision to participate in a FSSA followup in 2003 are welcome. In 2001, despite adverse conditions, the systemically important banks increased profitability and expanded their regulatory capital base. Also, the authorities have moved swiftly to strengthen the resources of the recently created FSA, improve management practices in the financial sector, and tighten regulations and supervision. Further along these lines, there is a need for additional tightening of loan classification, provisioning, and collateral valuation standards and monitoring. The authorities should be vigilant of emerging securities lending and investment banking activities. Prompt enactment of the financial legislation currently being discussed should lead to a strengthening of the supervisory mandate of the FSA and to its extension to the main financial activities.

28. Monetary policy should be firmly geared toward cementing confidence in the inflation-targeting regime and rapidly curtailing inflation, which will require a tight posture for some time. Although monetary conditions were largely accommodative during the past year, the recent appreciation of the exchange rate appears set to bring inflation back to within its target range by end-year and to the $2 \frac{1}{2}$ percent target rate in 2003 . With the exchange rate level currently roughly in line with medium-term stability and a sustainable external position, monetary conditions seem broadly appropriate. But the situation is still volatile and upside risks to the intended inflation path remain. Thus, the CBI should be cautious in reducing interest rates further and maintain a tight stance until there is evidence that inflation will stay low after the one-time measures that have contained prices wear off. In particular, the CBI should be vigilant to faster-than-envisaged consumption and credit growth. Given the resilience shown by economic activity and the ongoing pick-up in consumer confidence, tight monetary conditions are likely to be needed beyond the immediate future to avoid a re-emergence of earlier imbalances.

29. The operational procedures of the monetary framework could be improved to enhance their effectiveness. The predictability and transparency of the inflation-targeting policy framework could be enhanced by establishing regular monetary policy meetings of the Board of Governors of the CBI and publishing the detailed considerations that underlie its policy decisions. Also, consolidating the recently granted operational independence of the Central Bank and safeguarding its price stability mandate require that policy decisions be made without outside pressure. Regarding monetary operations, the CBI should consider reforming its liquidity facilities to encourage banks to resort to the interbank market and avoid money market distortions. 
30. The public finances and the authorities' medium-term budgetary plans are sound, but slippages have emerged and the fiscal framework needs to be strengthened. Owing to sustained fiscal consolidation efforts, Iceland enjoys a relatively low level of public debt in comparison to other OECD countries. The authorities' objectives of further reducing public debt and rapidly bringing the fiscal balance toward the medium-term target surplus of about 1 percent of GDP are appropriate. But expenditure slippages have occurred in recent years and budgetary discipline needs buttressing to address the expansion of current spending. In this regard, medium-term orientation of fiscal policy could be reinforced by introducing multi-year budget plans with explicit expenditure limits and cyclically-adjusted balance targets; and adopting national accounts reporting methodologies and coverage. Specific measures to contain future potential wage bill overruns should be adopted.

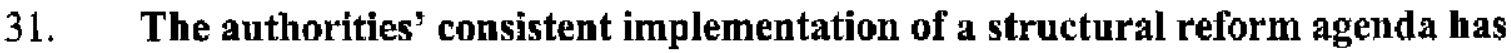
had evident growth pay-offs, and could be complemented by new initiatives. The recent tax reforms will simplify the tax system, bringing it closer to international practices, and increase incentives for saving and investing. Resumption of the privatization process in an improved market environment will allow further reduction of public debt and underpin investor confidence. The authorities are encouraged to consider expanding the private sector role in the provision of public services such as health and education and increasing the flexibility of the wage settlement process.

32. Staff welcomes the authorities' commitment to increase ODA allocations and encourages accelerating progress toward the U.N. target of 0.7 percent of GNP. The authorities are to be commended for their efforts to combat money laundering and other financial crime, which has earned Iceland a good international standing in this area.

33. It is proposed that Iceland's move to a 12-month Article IV consultation cycle be maintained through the next consultation, in view of the FSSA followup planned for 2003. 
Table 1. Iceland: Selected Economic Indicators

\begin{tabular}{|c|c|c|c|c|c|c|c|}
\hline & 1996 & 1997 & 1998 & 1999 & 2000 & $\begin{array}{c}2001 \\
\text { Oflicial } \\
\text { Estimate }\end{array}$ & $\begin{array}{c}2002 \\
\text { Official } \\
\text { Forecast }\end{array}$ \\
\hline & \multicolumn{6}{|c|}{ (Percentage change uless otherwise noted) } & \\
\hline \multicolumn{8}{|l|}{ Natlonal Accounts (constant prlees) } \\
\hline Gross domestic product & 5.2 & 4.6 & 5.0 & 3.6 & 5.5 & 3.0 & -0.5 \\
\hline Total domestic demand & 7.2 & 5.5 & 12.7 & 4.0 & 6.6 & -2.5 & -2.9 \\
\hline Private consumption & 5.4 & 5.5 & 10.0 & 6.9 & 4.4 & -2.8 & -1.0 \\
\hline Public consumption & 1.2 & 2.5 & 3.4 & 4.4 & 3.7 & 3.0 & 2.8 \\
\hline Gross fixed investment & 20.9 & 8.8 & 29.6 & -3.4 & 14.7 & -6.2 & -13.0 \\
\hline Expott of goods and services & 9.9 & 5.7 & 2.2 & 4.8 & 6.3 & 7,3 & 1.9 \\
\hline Inports of goods and services & 16.7 & 8.5 & 23.3 & 5.5 & 8.9 & .7 .9 & -3.6 \\
\hline Output gap $1 /$ & -2.4 & -0.1 & 1.5 & 1.6 & 3.5 & 3.1 & -0.3 \\
\hline \multicolumn{8}{|l|}{ Selected Indicators } \\
\hline Fish catch & 8.1 & -1.3 & -7.9 & -1.6 & -3.9 & -2.2 & 1.4 \\
\hline Uncmployment rate $2 /$ & 4.4 & 3.9 & 28 & 1.9 & 1.3 & 1.7 & 2.3 \\
\hline Real disposable income per capita & 4.1 & 2.4 & 8.8 & 4.0 & 1.6 & $-n .2$ & 0.8 \\
\hline Consumer price index & 2.3 & 1.8 & 1.7 & 3,4 & 5,0 & 6.7 & 5.2 \\
\hline Nominal wage indek & 6.4 & 5.4 & 9.4 & 6.8 & 6.6 & 8.9 & 6.9 \\
\hline Norniral effective exchange rate $3 /$ & -0.1 & 1.3 & 1.8 & 0.2 & -0.1 & -20.1 & -1.7 \\
\hline Real effective exchange rate (CPD) 3 / & 0.2 & 0.9 & 1.6 & 1.8 & 2.9 & -12.9 & 1.2 \\
\hline Terms of trade & -3.0 & 2.5 & 5.2 & 0.2 & -1.2 & 0.8 & 0.3 \\
\hline \multicolumn{8}{|l|}{ Money and Credit } \\
\hline Deposit morrey barlk crodit (end-period) & 12.0 & 12.7 & 30.4 & 23.2 & 24.5 & 17.3 & $\cdots$ \\
\hline Domestic credit (end-periond) & B.8 & 15.5 & 27.6 & 22.3 & 43.8 & 14.5 & $\ldots$ \\
\hline Broad moncy (end-period) & 6.8 & 8.7 & 15.2 & 17.0 & 11.0 & 15.5 & $\ldots$ \\
\hline \multirow[t]{2}{*}{ CBI policy rate (period average) } & 6.6 & 6.9 & 7.3 & 8.4 & 10.5 & 10.9 & $\ldots$ \\
\hline & \multicolumn{6}{|c|}{ (ln percent of GDF, unless otherwise noted) } & \\
\hline \multicolumn{8}{|l|}{ Public Flnance } \\
\hline \multicolumn{8}{|l|}{ Tretasury $4 /$} \\
\hline Revenut & 26.3 & 25.2 & 31.1 & 33.6 & 33.1 & 31.0 & 30.8 \\
\hline Expenditurc & 28.8 & 24.9 & 33.1 & 32.4 & 34.3 & 31.2 & 30.3 \\
\hline Balance $5 t$ & -2.5 & 0.2 & -2.0 & 1.2 & -1.2 & -0.2 & 0,5 \\
\hline Net borrowing requirement $f$ & 2.6 & 0.1 & 1.5 & -3.8 & -0.6 & 0.0 & .3 .2 \\
\hline General goverument balance $7 /$ & -1.6 & 0.0 & 0.5 & 2.4 & 2.4 & $\$ 1$ & -0.5 \\
\hline \multicolumn{8}{|l|}{ Balance of Payments } \\
\hline Current account balance & -1.8 & -1.6 & -7.0 & -6.9 & -10.1 & -4.4 & -2.0 \\
\hline Trade balarce (goods) & 0.2 & 0.0 & -4.4 & -3.6 & -5.6 & -0.8 & 0.8 \\
\hline Financial and capital account & 2.2 & 3.4 & 8.0 & 9.8 & 10.5 & 5.4 & $\ldots$ \\
\hline o/w: reserve assets $8 /$ & -2.1 & 0.6 & -0.4 & -0.9 & 0.8 & -1.1 & $\ldots$ \\
\hline Net eJrors and omissions & -0.5 & -1.8 & -1.0 & -2.9 & -0.4 & -1.7 & $\ldots$ \\
\hline Gross extemal dcbt g/ & 63.3 & 66.1 & 72.4 & 84.5 & 108.9 & 124.3 & $\cdots$ \\
\hline Debt service ratio $10 /$ & 22.6 & 19.2 & 21.7 & 25.3 & 37.1 & 49.0 & $\cdots$ \\
\hline Central bank gross reserves (in months & & & & & & & \\
\hline of imports of goods and services) & 2.1 & 1.8 & 1.6 & 1.8 & 1.5 & 1.4 & -- \\
\hline
\end{tabular}

Sources: National Economic Institute; Central Bank of 1celand; Ministry of Finance; and staff estimstes.

1/ Staff estimates. Actual minus potential output, in percent of potential output.

2/ In percent of labor fonce.

3/ A positive (negative) sign indicates an appreciation (depreciation).

4/ Cash basis through 1997; Accrual basis in 1998 and 1999.

S/ Excludes privatization reverues and payments to capitalize pension obligations.

6/ IrcLudes privatization revenues net of payments to capitalize pension obligations.

7/ National accouncs basis.

8/ A pasitive (negative) sign indicates a decrease (increase) in gross official foreign reserves.

g/ Extenal liabilitics mirus equity investment.

10/ Ratio of long-term external tebt service payments to exports of goods and services. 
Table 2. Iceland: Balance of Payments

(In millions of US dollars $\mathrm{V}$, unless otherwise indicated)

\begin{tabular}{|c|c|c|c|c|c|c|c|}
\hline & 1995 & 1996 & 1997 & 1998 & 1999 & 2000 & $20012 /$ \\
\hline Current account & 53 & -119 & -126 & -564 & -604 & -858 & -338 \\
\hline Balance on goods and services & 255 & 46 & 46 & -371 & -407 & -597 & -36 \\
\hline Exports of goods and services & 2493 & 2658 & 2699 & 2871 & 2936 & 2946 & 3113 \\
\hline Goods, fob & 1803 & 1890 & 1854 & 1925 & 2007 & 1898 & 2013 \\
\hline Marine products & 1297 & 1392 & 1323 & 1402 & 1353 & 1202 & 1249 \\
\hline Other goods & 506 & 498 & 531 & 523 & 654 & 696 & 764 \\
\hline Services & 690 & 769 & 844 & 946 & 930 & 1048 & 1100 \\
\hline Imports of goods and services & -2238 & -2612 & -2653 & -3242 & -3344 & -3543 & -3149 \\
\hline Goods & -1597 & -1871 & -1851 & -2278 & -2317 & -2374 & -2076 \\
\hline Services & -641 & -741 & -802 & -965 & -1027 & -1168 & +1074 \\
\hline Income balance & -198 & -158 & -168 & -179 & -187 & -252 & -292 \\
\hline Receipts & 92 & 116 & 104 & 120 & 119 & 153 & 156 \\
\hline Expenditures & -280 & -274 & -272 & -299 & -306 & -405 & -448 \\
\hline Current transfers, net & -5 & -7 & -3 & -14 & -10 & -10 & -10 \\
\hline Capital and funancial acconnt & -10 & 151 & 239 & 641 & 836 & 903 & 469 \\
\hline Capital transfers, net & -4 & 0 & 0 & -5 & -1 & -3 & 4 \\
\hline Financial account & -5 & 151 & 239 & 646 & 837 & 906 & 466 \\
\hline Financial account, excl. reserves & -2 & 304 & 194 & 678 & 911 & 838 & 421 \\
\hline Diręct investment, net & -35 & 19 & 94 & 76 & -41 & -229 & -124 \\
\hline Abroad & -26 & -63 & -51 & -71 & -106 & -387 & -297 \\
\hline In Iceland & .9 & 82 & 145 & 147 & 66 & 158 & 173 \\
\hline Portfolio investment, net & 154 & 109 & -244 & -237 & 590 & 499 & 487 \\
\hline Assets & 81 & -65 & -204 & -304 & -390 & -626 & -58 \\
\hline Equity Securities &.. & .. & -181 & -253 & -371 & -635 & -60 \\
\hline Debt Securities &.. &.. & -23 & -51 & -19 & 10 & 2 \\
\hline Liabilities & 235 & 174 & -40 & 66 & 980 & 1125 & 545 \\
\hline Equity Securities & -. &. & -1 & 14 & 56 & -43 & 44 \\
\hline Debt Securities & .. &. & -39 & 53 & 924 & 1168 & 502 \\
\hline Other capital, net & -121 & 176 & 344 & 839 & 361 & 568 & 57 \\
\hline Assets & 23 & -30 & -164 & 4 & -175 & -90 & -132 \\
\hline Liabilities & -144 & 206 & 507 & 835 & 536 & 658 & 189 \\
\hline Reserve assets ( = increase) & -4 & -153 & 45 & .32 & .74 & 67 & 45 \\
\hline Net errors and omissions & -43 & -32 & -113 & -77 & -232 & -45 & -131 \\
\hline \multicolumn{8}{|l|}{ Memorandum items: } \\
\hline Current account (in percent of GDP) & 0.8 & -1.8 & -1.6 & -7.0 & -6.9 & -10.1 & -4.4 \\
\hline Gross forejgn reserves of the Central Bank (end of period) & 312 & 458 & 388 & 430 & 500 & 438 & 377 \\
\hline Net foreign reserves of the Central Bank (end of petiod) & 215 & 462 & 389 & 373 & 448 & 237 & 224 \\
\hline Exchange Rate: ISK/US\$ (period average) & 64.7 & 66.5 & 70.8 & 71.0 & 72.2 & 78.7 & 97.6 \\
\hline
\end{tabular}

Sources: Central Bank of lceland; IMF, International Financial Statistics.

1/ Based on official estimates in domestic currency converted into US\$ at current exchange rates.

2/ Preliminary figures. 
Table 3. Iceland: Medium-Term Scenario

\begin{tabular}{|c|c|c|c|c|c|c|c|c|}
\hline & 2000 & 2001 & 2002 & 2003 & 2004 & 2005 & 2006 & 2007 \\
\hline \multicolumn{9}{|c|}{ (Percentage change) } \\
\hline Real domestie demand & 6.6 & -2.5 & -3.0 & -0.2 & 3.8 & 4.9 & 5.0 & 5.0 \\
\hline Private consumption & 4.4 & -2.8 & -10 & 1.4 & 2.0 & 2.8 & 3.2 & 3.2 \\
\hline Public consumption & 3.7 & 3.0 & 2.8 & 2.5 & 2.5 & 2.5 & 2.5 & 2.5 \\
\hline Gross fixed investment & 14.7 & -6.2 & -13.0 & -7.5 & 11.0 & 13.2 & 11.9 & 11.4 \\
\hline Public fixed investment & 8.9 & -0.8 & -7.1 & -1.0 & 3.0 & 5.0 & 3.5 & 3.5 \\
\hline Private fixed investment & 15.8 & -7.9 & -12.3 & -8.3 & 12.0 & 14.0 & 12.8 & 12.1 \\
\hline Exports of goods and services & 6.3 & 7.3 & 1.9 & 3.7 & 3.3 & 2.7 & 2.4 & 2.4 \\
\hline Exports of goods & 0.6 & 6.9 & 1.8 & 2.7 & 2.5 & 2.0 & 1.5 & 1.5 \\
\hline Exports of services & 18.9 & 8.2 & 2.1 & 5.5 & 4.8 & 4.0 & 4.0 & 4.0 \\
\hline Imports of goods and services & 8.9 & -7.9 & -3.6 & -1.2 & 4.0 & 5.3 & 5.1 & 5.2 \\
\hline Imports of goods & 3.8 & -8.1 & -4.1 & -1.0 & 4.0 & 5.3 & 5.1 & 5.3 \\
\hline Imports of services & 21.8 & -7.3 & -2.5 & -1.5 & 4.0 & 5.2 & 5.1 & 5.1 \\
\hline Real GDP & 5.5 & 3.0 & -0.5 & 1.7 & 3.6 & 3.8 & 3.9 & 3.9 \\
\hline Consumer price index & 5.0 & 6.7 & 5.2 & 2.2 & 2.2 & 2.8 & 3.3 & 3.3 \\
\hline Unemployment rate & 1.3 & \.7 & 2.3 & 2.6 & 2.8 & 2.9 & 2.9 & 2.9 \\
\hline \multicolumn{9}{|c|}{ (In percent of GDP) } \\
\hline Current Account & -10.1 & -4.4 & -2.0 & 0.1 & 0.0 & -0.9 & -1.8 & -1.9 \\
\hline Trade balance & -5.6 & -0.8 & 0.8 & 1.8 & 1.6 & 1.0 & 0.3 & -0.2 \\
\hline Services balance & -1.4 & 0.3 & 1.0 & 2.0 & 2.3 & 2.2 & 2.1 & 2.1 \\
\hline Factor income balance & $-3,0$ & -3.8 & -3.7 & -3.7 & -3.8 & -4.0 & -4.1 & -3.7 \\
\hline Net current transfers & -0.1 & -0.1 & -0.1 & -0.1 & -0.1 & -0.1 & -0.1 & -0.1 \\
\hline Capital and financial account & 10.5 & 5.4 & 3.2 & 2.9 & 2.7 & 3.2 & 3.3 & 2.8 \\
\hline Capital transfers, net & 0.0 & 0.0 & 0.0 & 0.0 & 0.0 & 0.0 & 0.0 & 0.0 \\
\hline Financial account & 10.6 & 5.5 & 3.2 & 2.9 & 2.7 & 3.2 & 3.3 & 2.8 \\
\hline \multicolumn{9}{|c|}{ Memorandum items (in percent of GDP): } \\
\hline Gross external debt & 108.9 & 124.3 & 125.5 & 126.7 & 126.5 & 125.5 & 124.1 & 122.0 \\
\hline General government gross debt & 41.6 & 46.8 & 41.9 & 39.5 & 36.6 & 33.6 & 30.5 & 27.7 \\
\hline Domestic debt & 18.7 & 17.7 & 14.4 & 13.5 & 12.5 & 11.5 & 10.5 & 10.5 \\
\hline Foreign debr & 22.9 & 29.0 & 27.6 & 26.0 & 24.1 & 22.1 & 20.1 & 17.2 \\
\hline General government net debt & 23.8 & 28.9 & 25.3 & 22.1 & 20.2 & 18.2 & 16.3 & 14.4 \\
\hline
\end{tabular}

Sources: National Economic Institute; Central Bank of Iceland; and staff projections. 
Table 4. Iceland: Financial Soundness Indicators

\begin{tabular}{|c|c|c|c|c|c|c|c|c|}
\hline & $14 \%$ & 1997 & lyఖs & 1999 & 2000 & 2001 & 2002 & wof \\
\hline & \multicolumn{8}{|c|}{ (In percent, unless otherwise indicated) } \\
\hline \multicolumn{9}{|l|}{ Capital aulequacy } \\
\hline Risk-based capital adequacy ratio (CAR) 1/ & 12.4 & 11,6 & 10.4 & 10,6 & 9.9 & 11.5 & $\ldots$ & \\
\hline CAR excluding subordinaited toans & 11.1 & 10.2 & $8 . \mathrm{B}$ & 8.2 & 6.7 & 8.2 & $\ldots$ & \\
\hline Tier l capital ratio & 12.1 & 11.3 & 100 & 9.6 & 8.4 & 9.2 & $\cdots$ & \\
\hline Equity as pereent of regulatory eapital & 92.6 & 92.9 & 86.7 & 82.9 & 80.9 & 68.5 & $\cdots$ & \\
\hline \multicolumn{9}{|l|}{ Asset quality } \\
\hline \multicolumn{9}{|l|}{ Credit Institutions } \\
\hline Total Lending (in ISK billion) 2f & 275 & 308 & 385 & 476 & 618 & 725 & 722 & March \\
\hline therefof forpign loans (in $\%$ ) & 29.0 & 31.8 & 34.4 & 36.5 & 41.6 & 44.3 & $41 . .4$ & March \\
\hline \multicolumn{9}{|l|}{ Sectoral credit concentration } \\
\hline Real estate loans (as \% of total bans) & 6.9 & 6.7 & 6.3 & 6.8 & 6.6 & 5.8 & 5.3 & Nfarch \\
\hline Loans to fisheries (as \% of total loans) & 28.7 & 29.4 & 27.7 & 24.8 & 22.9 & 21.2 & 20.5 & March \\
\hline thereof forcign loans (in \% $\%$ ) & 75.5 & 79.1 & 83.3 & 83.9 & 86.5 & 86.8 & 87,1 & March \\
\hline Loans to houscholds (as \% of total loans) $3 /$ & 25.9 & 26.6 & 27.9 & 27.3 & 27.5 & 25.5 & 26,3 & Marçh \\
\hline thereof fortign loans (in \%) & 0.3 & 0.5 & 1.8 & 4.8 & 8.1 & 10.4 & 9.7 & March \\
\hline Lpans to businesses (as $\%$ of total loans) & 65.5 & 65.2 & 64.8 & 65.7 & 65.2 & 64.2 & 63.3 & March \\
\hline thereof foreign bans (in \%) & 43.6 & 46,8 & 49,8 & 50.6 & 55.6 & $\$ 4.7$ & 53.6 & Mareh \\
\hline Lanns to retail and services (as \& of total loans) & 20.8 & 19.8 & 24.8 & 28.6 & 29.4 & 30.0 & 29.9 & March \\
\hline thereof foreign loans (in \%) & 14.0 & 15.2 & 19.5 & 29.5 & 37,0 & 36.1 & 34.1 & Marub \\
\hline Loans to manufauturing et. al. (as \% of total loars) & 16.0 & 16.0 & 12.3 & 12.2 & 12.9 & 13.0 & 12,9 & March \\
\hline thereof foreign loaths (in \%) & 24,5 & 26.7 & 35.5 & 32.4 & 43.0 & 45.3 & 45.2 & March \\
\hline Non-performing loens (NPL) as $\%$ of tocal loans 4 & 5.1 & 3.8 & 2.4 & 2.5 & 2.2 & 3.0 & $\ldots$ & \\
\hline Loan-lass provisions as \% of NPL S/ & 44.8 & 45.6 & 51.9 & 50.5 & 51.5 & 46.8 & $\ldots$ & \\
\hline Connested lending & n.a. & b.a. & a.a. & n.a. & л.а. & n.a. & $\ldots$ & \\
\hline Off-bal, sheet exposure (wout OTC deriv.) as \% of reg- capital & 114.9 & 143.8 & 159.7 & 135.5 & 120.0 & 70.5 & $\cdots$ & \\
\hline Off-ba]. sheet exposure (with OTC deriv.) os \% of reg. capital & 116.7 & 147.1 & 163.4 & 140.4 & 135.1 & $\$ 1.4$ & $\ldots$ & \\
\hline Foreign-currency den. assets as $\%$ of total absets & 2t.J & 30,0 & 27,0 & 31.1 & 44.6 & 44.8 & $\ldots$ & \\
\hline Foreign-currency den. liabilites as \% of lotal assets & 20.6 & 29.6 & 27.4 & 31.6 & 45.0 & 44.7 & w.+ & \\
\hline Leverage ratio (equity as \% of total assels) & 7.9 & 7.4 & 7.0 & 6.8 & 6.7 & 6.5 & $\cdots$ & \\
\hline \multicolumn{9}{|l|}{ Borrowing entitieg } \\
\hline \multicolumn{9}{|l|}{ Debat-equity ratios } \\
\hline All listed compenies (except financial companies) & 1.82 & 1.96 & 1.85 & 1.96 & 2.21 & 2.27 & $\cdots$ & \\
\hline Fisheries companits & 1.95 & 1.67 & 1.75 & 1.87 & 2.57 & 2.59 & $\ldots$ & \\
\hline Manufacturing campanies & 1.14 & 2.41 & 1.11 & 1.40 & 1.62 & 1.72 & $\cdots$ & \\
\hline IT cempanies & & & 2.80 & 2.28 & 1.90 & 2.60 & $\cdots$ & \\
\hline Retail, services, and construetion companies & $\ldots$ & 2.10 & 2.39 & 2.28 & 1.94 & 1.71 & $\ldots$ & \\
\hline \multicolumn{9}{|l|}{ Corporate profitability (EBITDA'turnover) } \\
\hline All liłtęd companies (except financial companiex) & $\ldots$ & 8.0 & 8.2 & 7,3 & 9.2 & 11.0 & $\ldots$ & \\
\hline Fisheries companies & 15.8 & 16.5 & 17.8 & 14.7 & 17.2 & 282 & $\cdots$ & \\
\hline Mübufacturing cotupanies & 17.7 & 10.7 & 7.2 & 7.5 & {$[3.2$} & 13.5 & $\ldots$ & \\
\hline IT eomparies & & & 6.1 & 8.7 & 9.6 & 1.2 & $\ldots$ & \\
\hline Retail, services, and construction companies & $\ldots$ & 9.3 & 2.2 & 5.6 & 14.7 & 12.6 & $\ldots$ & \\
\hline Houschold indebtedness (debt'disposable income) & 133.4 & 134.7 & $\$ 38.7$ & 145.8 & 159.5 & 1709 & '" & \\
\hline \multicolumn{9}{|l|}{ Management soludness $1 /$} \\
\hline \multicolumn{9}{|l|}{ Expense ratios } \\
\hline Operating expenses as \% of gross income & 66.6 & 65.3 & 67.1 & 60.4 & 66.3 & 66.1 & $\ldots$ & \\
\hline Opes ating expences as $\%$ of average total assets & 4.7 & 4.4 & 4.1 & 3.7 & 3.1 & 2.9 & $\cdots$ & \\
\hline Seaff costs as $\%$ of avg. bal. sheet total & 2.4 & 2.3 & 2.1 & 3.9 & 1.6 & 1.5 & $\ldots$ & \\
\hline Staff costs as \% $\%$ grass incone & 33.9 & 39.6 & 35.2 & 31.2 & 33.2 & 33.5 & $\cdots$ & \\
\hline Eamings per employee (gross inc./employees) (Kr. Millions) & 7.7 & 8.3 & 8.9 & 10.9 & 12.4 & $1 ; 1.1$ & $\ldots$ & \\
\hline Earnings per brauch (gross inc,fthraches) (Kr. Millions) & 107.7 & 119.0 & 131.9 & 171.4 & 210.5 & 231.4 & $\ldots$ & \\
\hline
\end{tabular}


Table 4. Iceland: Financial Soundness Indieators (conchuded)

\begin{tabular}{|c|c|c|c|c|c|c|c|c|}
\hline & 1996 & 1997 & 1998 & 1999 & 2000 & 2001 & 2002 & as of \\
\hline \multicolumn{9}{|l|}{ Earninga and profitability! } \\
\hline Returt ot assets & 0.8 & 0.9 & 0.9 & 1.3 & 0.6 & 0.8 & $\ldots$ & \\
\hline Retum on equity & 3.5 & 10.3 & 13.5 & 19.3 & 9.9 & 13.7 & $\ldots$ & \\
\hline Interest income (1s $\%$ of total Icvenuc) & 62.1 & 58.9 & 56.0 & 52.4 & 54.3 & 63.4 & $\ldots$ & \\
\hline \multicolumn{9}{|l|}{ Nom-interest income (nel) as $\%$ of gross income } \\
\hline Fees and commissions (as \% totsl revenue) & 24.8 & 24.5 & 23.1 & 23.1 & 31.4 & 32.1 & $\ldots$ & \\
\hline "Fees and commiss. payable as \% gooss itacome & (2.1) & $(2.2)$ & $(3.2)$ & (3.6) & $-6,5$ & -5.7 & $\ldots$ & \\
\hline Net profit or loss on financial operations (as \% of total revenue) & 5.3 & 7.5 & 15,0 & 12,0 & $(0,4)$ & (5.9) & ... & \\
\hline Dividends from shates and other holdinges (as \% of total requenue) & 4.7 & 6.1. & 3.9 & 9.6 & 5.9 & 4.0 & $\ldots$ & \\
\hline Other income (as $\%$ of total covedue) & 3.1 & 3.1 & L.y & 2.9 & 9.8 & 6.5 & $\cdots$ & \\
\hline \multicolumn{9}{|l|}{ Liquidity: } \\
\hline Central bank credil to banks (end of period, in ISK billion) & $\ldots$ & $\ldots$ & 22.8 & 36.0 & 46,9 & 68.7 & 80.7 & April \\
\hline Deposits to $\mathrm{M} 3$ ratio & 0.97 & 0.97 & 0.97 & 0.97 & 0.98 & 0.98 & 0.98 & March \\
\hline Loans-to-depnsits ratio & 1.25 & 1.29 & 1.46 & 1.53 & 2.07 & 2.09 & 2.04 & Merch \\
\hline \multicolumn{9}{|l|}{ Lipuidity ratio (cash and short-term assets' } \\
\hline demand and short-term liabilities) & $\ldots$ & $\ldots$ & $\ldots$ & $\ldots$ & 1.2 & 1.2 & 1.2 & March \\
\hline \multicolumn{9}{|l|}{ Measures of secontary markel liquidity: } \\
\hline Interbank FX market tumover (R. Billions) & 80.8 & 162.2 & 401.7 & 468.0 & 768 & 1,218 & 251.6 & April \\
\hline Interkank domestie murket turnover (Kr. Billions) & $\ldots$ & $\ldots$ & 447.7 & 502.9 & 324.28 & 426.1 & 124.3 & Appril \\
\hline \multicolumn{9}{|l|}{ Indicators of segmentation of the money } \\
\hline market (difference betwoen interbank leqnding ratess) & $\cdots$ & $\cdots$ & $\ldots$ & 5.8 & $\ldots$ & $\cdots$ & $\cdots$ & \\
\hline \multicolumn{9}{|l|}{ Market-based Indleators: } \\
\hline Stexk market index (ICEX-15; y-o-y change) & 59.3 & 14.7 & 9.8 & 47.4 & (19.3) & (11.2) & 13.8 & April \\
\hline Equity prices of fithancial institutions (yoory increase) & 31.08 & 82.9 & $\$ 1.7$ & 70.8 & $\ldots$ & $\ldots$ & & \\
\hline Residential housing prices $\{y-\sigma-y$ inctease $\}$ & 1.0 & 2.7 & 7.3 & 21.9 & 13.5 & 3.3 & ... & \\
\hline Commercial propenty prices ( $y-0-y$ increase $)$ & 10.8 & 1.7 & 20.0 & 27.3 & 19.5 & (7.9) & $\ldots$ & \\
\hline Pricejearnings ratio & $\ldots$ & $\ldots$ & 19.3 & 21.7 & $\ldots$ & $\ldots$ & & \\
\hline Market capitalization at year-end/GDP $6 /$ & 19.5 & 28.5 & 39.9 & 57.6 & 59.5 & 57.0 & 60.7 & Marcl2 \\
\hline Turnover rate (Irading/market capita]ization) & $\ldots$ & 15.6 & 17.2 & 32.4 & 30.6. & 32.3 & 38.7 & March \\
\hline Interest rate spreads on borrowitg (average) & 6.6 & 6.3 & 5.1 & 4.3 & $\ldots$ & $\ldots$ & ... & \\
\hline \multicolumn{9}{|l|}{ Credit ratings } \\
\hline Moody's shorl-term & $\ldots$ & $\ldots$ & $\mathrm{Pl}-\mathrm{P} 2$ & $P 1-P 2$ & $\mathrm{Pl}=\mathrm{P} 2$ & P1-P2 & P1-P2 & Marche \\
\hline Moody's long-term & ... & $\ldots$ & $A 2-A_{3}^{3}$ & $\mathrm{~A}^{2}-\mathrm{A} 3$ & $A 2-A^{3}$ & A2-A3 & $A 2-A^{3}$ & March \\
\hline Fitch short-term & $\ldots$ & $\cdots$ & .. & $\ldots$ & $\ldots$ & FI & Fl & Maxth \\
\hline Fitch long-term & ++ & $\ldots$ & $\cdots$ & $\ldots$ & $\cdots$ & A & A & March \\
\hline \multicolumn{9}{|l|}{ Sovereign yield spreads (spread between yields on } \\
\hline Icelendic and foreign (trade-wcighted 3-month T-bills) & 2.8 & 27 & 3.4 & 5.7 & 6.3 & 7.9 & 6.0 & April \\
\hline \multicolumn{9}{|l|}{ FInancial market structure: } \\
\hline \multicolumn{9}{|l|}{ Conoentration ratios in the banking sector } \\
\hline Nutribet of banks sccounting for $25 \%$ of total assets & 1 & 1 & 1 & 1 & 1 & 1 & $\ldots$ & \\
\hline Number of banks accounting for $79 \%$ of 10tal assets & 3 & 3 & 3 & 3 & 3 & 3 & $\ldots$ & \\
\hline Number of financial itstittetons & 33 & 31 & 30 & 29 & 29 & 29 & $\ldots$ & \\
\hline
\end{tabular}

Sources: Finnencial Supervisory Autherily and Central Barik of Icelend.

1/ Deposit money hanks, i.e., commercjal banks and savings banks. Consolidated becounts.

2/ Deposit money banks. In the year 2000 FBA was merged to fslandsbanki which partly explain considetable jucrease ti figutes.

$3 /$ Inciudes private business cperations of jndividuals.

4/ Nęt of specifie provisions and including appropriated assets. Commercial banks and savings banks. FBA and its predecessors included.

5/ Stock of gonetal athd specitle provisious over stock of non-petforming loans. Commencjal bands and savings banks. FBA and its predectesqons incluobed

6.' lnclucing equity nutusl funds. 
Table 5. Iceland: Indicators of External and Financial Vulnerability

\begin{tabular}{|c|c|c|c|c|c|c|}
\hline & 1996 & 1997 & 1998 & 1999 & 2000 & 2001 \\
\hline \multicolumn{7}{|l|}{ External indicators } \\
\hline Exports of goods and services (annual percentage change, in U.S. dollars) & 6.7 & 1.3 & 6.6 & 2.6 & -0.2 & 6.4 \\
\hline Imports of goods and services (annual percentage change, in U.S. dollars) & 16.8 & 1.3 & 22.5 & 3.0 & 5.8 & -10.5 \\
\hline Terms of Trade (arnual percentage change) & -3.0 & 2.5 & 5.2 & 0.2 & -1.2 & 0.8 \\
\hline Foreign direct investment, net (in percent of GDP) & 4.2 & 2.6 & 8.5 & -0.5 & -2.3 & -1.6 \\
\hline Portfolio investnent, net (in percent of GDP) & 1.7 & -3.3 & -2.9 & 6.9 & 5.9 & 6.3 \\
\hline Othet investmcnt, net (in percent of GDP) & 2.4 & 4.8 & 10.5 & 4.2 & 6.2 & 0.7 \\
\hline Gross official reserves (in millions of U.S. dollars) & 458 & 392 & 419 & 495 & 445 & 327 \\
\hline in months of next year's imports & 2.1 & 1.5 & 1.5 & 1.7 & 1.7 & 1.3 \\
\hline Net official reserves (it millions of U.S. Dollars) & 462 & 393 & 364 & 443 & 237 & 225 \\
\hline Gross external debs (in percent of GDP) $3 /$ & 63.3 & 66.1 & 72.4 & 84.5 & 108.9 & 124.3 \\
\hline Net external liabilities (in percent of GDP) & 46.9 & 46.8 & 50.2 & 49.7 & 66.9 & 81.3 \\
\hline Foreign assets of the financial system (in percent of toral assets) & 6.1 & 7.3 & 9.1 & 13.4 & 13.8 & 13.51 \\
\hline thereof Depasit Money Banks (in pescent of total asscts) & 3.1 & 4.3 & 3.2 & 3.6 & 3.9 & 6.31 \\
\hline Foreign liabilities of the financial system (in percent of total absets) & 33.0 & 32.7 & 34.3 & 37.0 & 43.8 & 47.81 \\
\hline thereof Deposit Moncy Eatrks (in pereent of total assets) & 18,3 & 23.1 & 27.6 & 34.0 & 50.8 & $53.3 \mathrm{H}$ \\
\hline Rcal effective exchange rate (CPI) (curnulative yoy-change; $(+)$ appreciation) & 0.2 & 0.9 & 1.6 & 1.8 & 2.9 & -12.9 \\
\hline
\end{tabular}

Sources: Financia] Supervisory Authority, Centra] Bank of lceland, Statistics Iceland.

1/ End-September achuals.

2/ Based on freely usable reserves (excluding contigent credit lines) aver short-term debt on an orginial maturity busis.

3/ Dcbt figures are based on end-of-perjod exchange values, while GDP is valited at average-of-pcriod rates. 
Table 6. Iceland: Summary Operations of the General Government $1 /$

\begin{tabular}{|c|c|c|c|c|c|c|c|}
\hline & 1996 & 1997 & 1998 & 1999 & 2000 & $\begin{array}{r}2001 \\
\text { Official } \\
\text { Estimate }\end{array}$ & $\begin{array}{r}2002 \\
\text { Official } \\
\text { Forecast } 2\end{array}$ \\
\hline & \multicolumn{7}{|c|}{ (In pereent of GDP) } \\
\hline Total revenne & 39.1 & 39.3 & 40.6 & 43.2 & 42.9 & 41.2 & 41.2 \\
\hline Current revente & 36.9 & 37.2 & 38.5 & 41.1 & 40.9 & 39,2 & 39.2 \\
\hline Capital revenue & 2.2 & 2.1 & 2.1 & 2,0 & 2.0 & 2.0 & 2.0 \\
\hline Total expenditure & 40.7 & 39.3 & 40.1 & 40.8 & 40.5 & 41.3 & 41.7 \\
\hline $\begin{array}{l}\text { Current expenditure } \\
\text { of which: }\end{array}$ & 35.3 & 34.4 & 34.6 & 35.5 & 35.7 & 36.4 & 37.3 \\
\hline Intcrest expenditure & 4.0 & 3.7 & 3.7 & 3.7 & 3.4 & 3.5 & 3.3 \\
\hline Capital expenditure & 5.3 & 4.9 & 5.5 & 5.3 & 4.8 & 4.9 & 4.4 \\
\hline Primary balance & 1.6 & 2.8 & 4.0 & 5.7 & 5.2 & 2.7 & 1.9 \\
\hline Overall balance & -1.6 & 0.0 & 0.5 & 2.4 & 2.4 & -0.1 & -0.5 \\
\hline \multicolumn{8}{|l|}{ Debt position } \\
\hline General govemment gross debt & 56.6 & 53.3 & 48.9 & 44.2 & 41.6 & 46.8 & 41.9 \\
\hline Domestic Debt & 28.5 & 27.7 & 26.7 & 23.0 & 18.7 & 17.7 & 15.9 \\
\hline Foreign Debt & 28.1 & 25.6 & 22.2 & 21.1 & 22.9 & 29.0 & 26.1 \\
\hline General government net debt & 39.5 & 37.5 & 31.5 & 23.9 & 23.8 & 28.9 & 25.3 \\
\hline & \multicolumn{7}{|c|}{ (In percent of potential GDP, unless otherwise indicated) } \\
\hline \multicolumn{8}{|l|}{ Cyclically adjusted } \\
\hline Primary revenue & 37.7 & 38.0 & 39.2 & 41.7 & 41.2 & 39.5 & 39.6 \\
\hline Primsary expenditure & 35.4 & 35.5 & 37.2 & 37.9 & 38.9 & 39.5 & 38.3 \\
\hline Primary balance & 2.3 & 2.5 & 2.1 & 3.8 & 2.3 & 0.1 & 1.4 \\
\hline Total revenue & 39.1 & 39.3 & 40.6 & 43.2 & 42.8 & 41.1 & 41.2 \\
\hline Total expenditure & 39.3 & 39.2 & 40.9 & 41.7 & 42.4 & 43.1 & 41.5 \\
\hline Overall balance & -0.2 & 0.0 & -0.4 & 1.5 & 0.4 & -2.0 & -0.3 \\
\hline \multicolumn{8}{|l|}{ Memorandum items: } \\
\hline Real expenditure change 4/ & 3.5 & 1.1 & 7.0 & 5.5 & 4.6 & 5.3 & 0.4 \\
\hline Output Gap 5/ & -2.4 & -0.1 & 1.5 & 1.6 & 3.5 & 3.1 & -0.3 \\
\hline
\end{tabular}

Sources: Ministry of Finance; National Economic Institute; and staff eștimates.

1/ Accrual basis.

2/ Ofticial forecast of the National Economic Institute as of March 2002.

4/ Change in percent.

5/ Actual output less potential in percent of potential. 


\section{Financial Sector Developments ${ }^{1}$}

1. Overall Iceland's financial sector appears to have weathered the severe economic developments of 2001 well, as trading and loan losses were offset by high interest margins, asset value gains generated by inflation and depreciation, and some consolidation of expenses in the banking sector. Icelandic banks recorded increased profits in 2001 and bolstered their regulatory capital positions, while pension funds are expected to record nominal returns that pace the domestic inflation rate.

2. Icelandic banks recorded an average return on equity in excess of 15 percent in 2001, an increase of 10 percentage points over 2000 results despite higher loan loss provisions and the dilution associated with increased capitalization. Return on assets reached almost 0.8 percent in 2001 , more than twice the average rate reported in 2000 . Savings banks, while profitable, did not fare as well, as increased loan loss provisions, interest expenses, and operating costs reduced their return on assets relative to 2000 .

3. Banks' asset quality deteriorated in 2001 , as loan performance in the consumer and retail service sector suffered from weakening domestic demand. Banks reported that foreign currency denominated loans performed well despite the depreciation of the króna as the application of selective qualifying criteria for foreign currency denominated borrowings helped to boost loan portfolio performance. In commercial banks, the ratio of nonperforming loans (NPLs) to total loans increased to 2.9 percent in 2001. Savings banks experienced more difficult conditions as their NPL ratio increased to 6.3 percent in 2001. Both commercial and savings banks increased loan loss provisions to account for the deterioration in the quality of their credit portfolios, but the size of their loan loss provisions (discussed below) are low relative to international best practice standards.

4. Icelandic banks increased their regulatory capital adequacy ratios in 2001 as they issued subordinated debt and new shares to finance strategic acquisitions. Following amendments to Iceland's regulatory framework in late 2000 , and encouraged by the Financial Supervisory Authority (FSA), Icelandic banks raised over ISK 25 billion in additional own funds over 2001, about one-fifth of which was raised using Tier 1 qualifying subordinated debt. $^{2}$ At end-2001, the capital adequacy ratio of Icelandic banks averaged 11.5 percent, and all systemically important institutions exceeded regulatory minimum requirements.

\footnotetext{
${ }^{1}$ Prepared by Messrs. Kupiec and Song (Monetary and Exchange Affairs Department).

${ }^{2}$ Under a 1998 Basel Committee opinion, hybrid capital instruments that satisfy a set of specific criteria may be included in Tier 1 capital up to a maximum of 15 percent. The subordinated debt issued by Icelandic banks have characteristics that were designed to satisfy the Tier 1 capital criteria. They are similar (in all but name) to perpetual nonparticipating, non-cumulative, non-voting preferred stock.
} 
5. The proactive approach adopted by the FSA was instrumental in improving the situation of the banking system and management practices, including through issuing guidance, and moral suasion. A more detailed analysis of the banking sector is provided in Box 1.

6. Outside of the banking sector, pension funds' returns suffered from weak capital markets conditions. While pension funds are likely to report returns on assets that are well in excess of those recorded in the banking system, pension funds' (and the FSA's) reports focus on real (inflation corrected) pension fund returns, which were slightly negative in 2000 and are expected to be slightly negative again in 2001. It is important to note that pension funds posted high real returns over the second half of the 1990s and the demographics of Iceland's population dictate that their net premium inflows will remain largely positive over the next two decades.

7. Both pension funds and Iceland's Housing Finance Authority (HFA) have significant exposure to residential mortgage lending. The HFA guarantees the payments on Housing Finance Bonds and in some instances borrows in the capital markets and lends directly to finance real estate purchases associated with social policy objectives. Pension funds purchase a large share of Housing Finance Bonds and also engage in direct real estate lending, much of it in the form of loans to their members. Figure 1 plots the delinquency rate (payments more than one-month past due) on the HFA's mortgage portfolio along with the average NPL rates reported by commercial banks and savings banks. Figure 1 shows that the delinquency rate on Housing Finance Bonds, while lower than the NPL rates reported by banks, has started to increase as the economic environment has hampered borrowers' ability to service loans.

Figure 1: Loan Cre dit Quality in Iceland

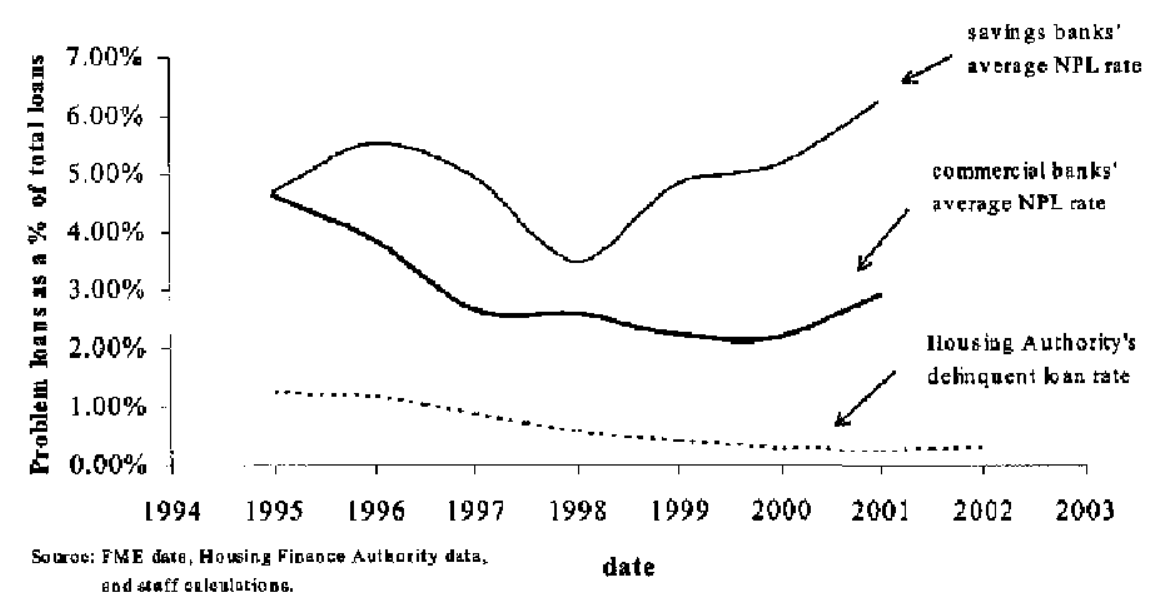


Box 1: Banking Conditions

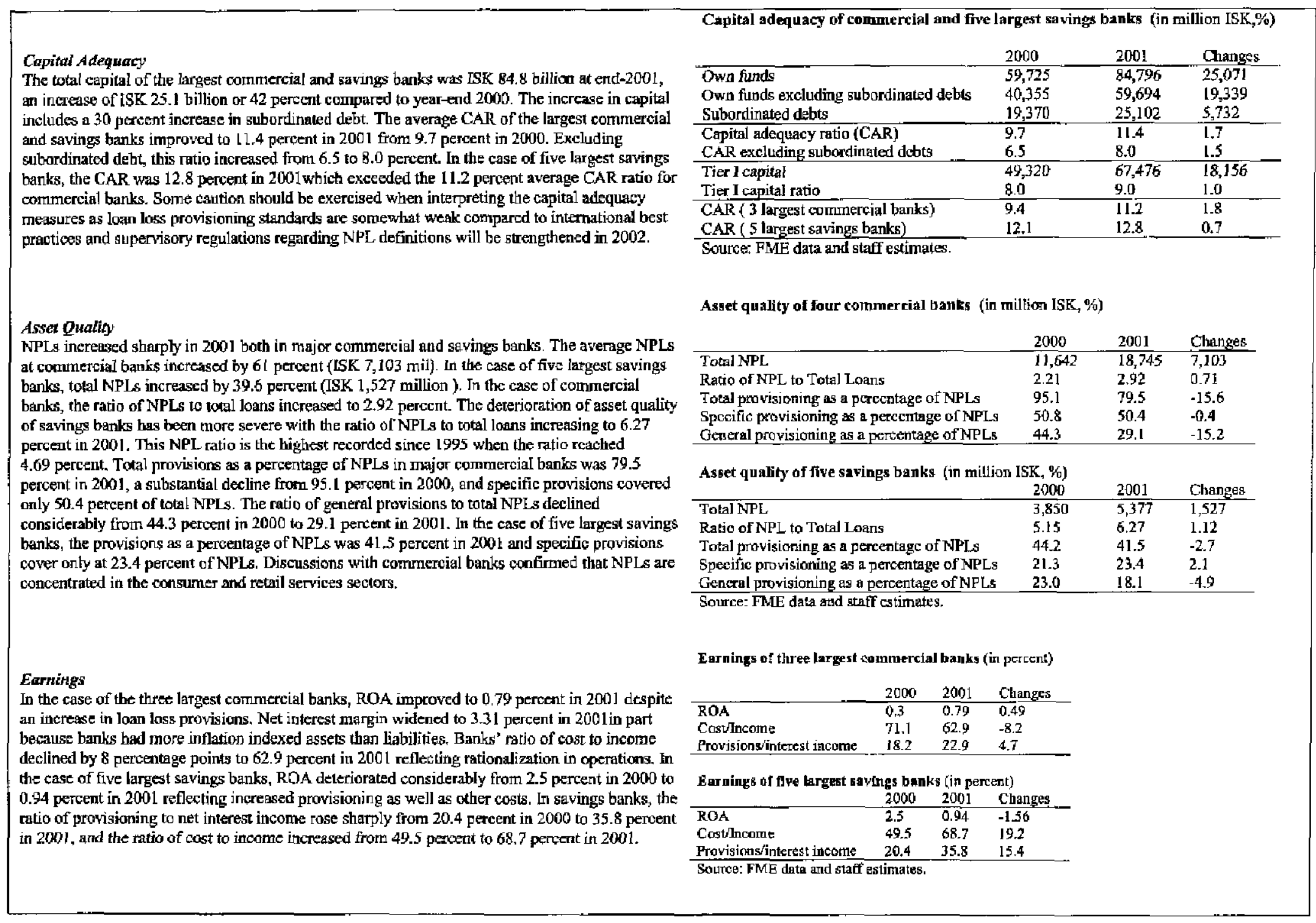

CInternational Monetary Fund. Not for Redistribution 


\section{Potential Risks and Financial Stability Issues}

8. While the financial sector is at present profitable and reasonably well capitalized, there are a number of outstanding issues that could generate financial sector risks going forward. These issues relate primarily to credit quality and provisioning, future bank funding strategies, rapid growth in investment banking style activities, and technical issues related to monetary policy operations.

9. Banks, pension funds, and the HFA expect additional increases in non-performing loans in 2002 if sluggish domestic sector conditions persist. Regardless, regulatory changes will reduce the delinquency time that must pass before a loan is legally classified as nonperforming. In 2001, a loan was nonperforming after payments were delinquent for six-months; the delinquency period is reduced to three-months from 2002 onwards.

10. Banks' provisions for nonperforming loans increased sharply in 2001, but their provisioning standards are less demanding than international best practice. Provisioning standards were clarified by new FSA regulations issued in 2001 and 2002, under which each institution is responsible for formulating its own internal rules regarding assessments for specific and general provisions, and specific provisions should be based upon the total commitments to borrowers less the probable proceeds that could be generated by any collateral held against these commitments. ${ }^{3}$

11. Interviews with banks suggested that loan loss provisioning and collateral valuation procedures are linked to the regulatory reporting frequency and definitions. Collateral is typically valued only twice a year, and provisions are not made on an anticipatory basis for performing but questionable loans or delinquent loans that do not yet satisfy the regulatory definition for a nonperforming loan. In 2001, commercial banks appeared to be assuming that 50 percent of the value of NPLs could be recovered by liquidating collateral. Savings banks implicitly assumed higher recovery values.

12. The collateral valuation estimates implicit in banks' loan loss provisions might be optimistic. In prior years, Icelandic financial institutions provisioned for a higher percentage of their NPLs' value. Bank collateral generally excludes residential properties (which collateralize guaranteed Housing Authority Bonds), and collateral values are difficult to monitor and highly uncertain during times of economic weakness. Prudence would have suggested that recovery rate estimates decline in 2001 to reflect the weakness in domestic conditions.

13. The recovery assumptions implicitly used to set loan loss provisions suggest that provisions are likely to be understated in 2001 . Moreover, under current regulations, specific

${ }^{3}$ Appendix I of Rules on the annual accounts of credit institutions No. 692 of September 10, 2001 , as amended by rule No.51 of 2002. 
provisions are not required until a loan satisfies the regulatory definition of a nonperforming loan. According to international best practices, specific provisions should not only cover NPLs but also include a component for performing loans that are precarious in view of borrowers' repayment capabilities.

14. While the authorities were of the opinion that Icelandic loan loss provisioning standards were consistent with Nordic country best practices, they agreed to investigate this issue and indicated their intention to strengthen supervisory guidance on loan loss provisioning if their findings suggest that such measures are appropriate. ${ }^{4}$

15. Housing loans are inflation indexed, while housing prices have recently been declining in real terms. If short-term trends persist, existing real estate loan-to-value ratios will rise, debt-servicing burdens will increase, and the favorable performance of the real estate loan portfolios of pension funds and the HFA likely will deteriorate.

16. As the banking system's capacity to generate capital through the use of subordinated debt is mostly exhausted, continued growth in lending must be capitalized with new equity and retained earnings. Some banks reported that their policies include a generous target dividend payout ratio and allow for share repurchases when their capitalization exceeded a maximum target level. Given the growing importance of international capital markets as a source of bank finance, it is important for the FSA and the banks to reconcile bank growth targets, funding strategies, payout policies, and target capital adequacy ratios with the need to maintain the confidence of international investors. Pending legislation which empowers the FSA to mandate an increase in the banks' regulatory capital when warranted by risks will enhance prudential supervision in this regard.

17. Some pension funds lend tepo-eligible securities to banks, either directly or through asset swap agreements. While such practices are not necessarily a prudential concern, the risk management controls that surround these transactions appear weak. At present, there are no regular reporting requirements regarding securities lending (or borrowing) activities and no regulatory guidance has been issued regarding specific risk management protocols for these activities. A significant portion of pension fund assets are under bank management, so there is scope for moral hazard if this relationship is not conducted under "arms-length" principles. The FSA is in the process of formulating an appropriate policy response, and it has surveyed market participants to assess the importance of these developments.

18. The high level and rapid growth of liquidity lending through the repo facility of the Central Bank of Iceland (CBI) may be replacing regular sources of bank financing and

\footnotetext{
${ }^{4}$ Rules No. 692/2001 and 51/2002 state that the FSA can require a bank to increase its level of loan loss provisions should the FSA find that the bank does not comply with regulatory standards for loan loss provisioning.
} 
distorting the cost of funds and the pricing of risk. Over the last years, the interbank market has virtually been reduced to overnight lending while turnover in other maturities as well as overall tumover have steadily declined. Thus, banks may be increasingly relying on direct CBI lending beyond their structural liquidity needs without the disciplining mechanism typically provided by markets (e.g., through differential pricing according to risk or maturity). For example, repo generated liquidity could be used to finance short-term bank loans supporting leveraged positions in domestic and international securities and other investment banking operations - without an added risk premium cost. Staff suggested that the authorities consider reforms in the CBI liquidity operations with a view to encouraging banks to resort to interbank borrowing and to limit the demand for CBI funds to the structural liquidity needs of the banking system. The authorities shared the staff's concerns and were studying the design of central bank lending facilities in other Nordic and inflation-targeting countries as well as strengthening their liquidity forecasting capabilities.

19. The development of international investment banking activities, such as short-term margin lending, poses challenges for financial regulators. At present, the regulators do not have procedures that are fully adequate for monitoring and regulating large investment banking style operations. The current regulatory framework is primarily designed to monitor traditional banking activities and reporting cycles are too infrequent for the task of monitoring banks predominantly engaged in margin lending, derivatives, and securities market activities. The authorities are aware of these issues, and staff encouraged them to continue working on developing policies, procedures, and understandings with host country supervisors aimed at improving the FSA's ability to monitor domestic and international investment banking activities and enhance consolidated supervision.

20. At present, the central bank's reserve requirements for all bank liabilities must be satisfied in domestic currency. This approach has the potential to create liquidity management difficulties for the banking system in case of exchange rate volatility, as unforeseen variations in the domestic currency value of foreign currency liabilities alters banks' need for liquidity to satisfy domestic reserve requirements. The potential for liquidity stress could be reduced if reserve requirements for foreign currency liabilities could be satisfied by foreign currency reserves.

21. A final issue affecting financial stability is the connectedness of the financial markets in Iceland. Banks are significant counterparties in securities market making, non-pension fund related asset management, and the management of pension funds. In many of these activities, there are well-known moral hazard and principal-agent conflicts of interest with the potential for loss of investor's confidence. Recent cases involving enforcement of insider trading regulations demonstrate the FSA's resolve in this area. Legislation has been drafted that will increase the FSA's powers regarding consolidated supervision and the regulation of connected lending. 


\section{FSAP Related Progress}

22. The authorities have made a coordinated effort at addiressing the issues raised in the 2001 FSSA report. The FSA was active in encouraging banks to strengthen their capital adequacy positions. Changes in the legal basis have been drafted, though in many areas legal and regulatory responses have yet to be finalized or implemented. In a number of cases where new regulations have been issued (e.g., loan loss provisioning and nonperforming loan valuation), the new rules represent significant improvements over prior guidelines, though remaining less proscriptive than staff would consider optimal. Following the recommendations of the 2001 FSSA, many of which were largely aligned with the FSA's own initiatives, regulatory authorities have increased staff and facilities, engaged in a more active program of on-site focused examinations, and issued regulatory opinions and guidelines to clarify regulations or provide guidance on interpretation. Finally, progress in supervision and regulation awaits the passage of new legislation. The authorities anticipate that the planned legislative changes will convey the proposed powers and responsibilities to the FSA in 2003.

\section{Financial Sector Recommendations}

The following recommendations were discussed with the authorities, who shared their general thrust.

- Given the size of Iceland's economy, banks' domestic portfolios cannot be well diversified and increasingly banks are relying on international capital markets for funding their activities. Authorities were encouraged to continue to promote capital deepening through greater earnings retention in order to promote investor confidence and minimize the potential for liquidity disruptions.

- Regulatory authorities are encouraged to become even more proactive in issuing supervision and regulation guidance. For example, it was recommended that authorities offer additional guidance on issues such as: acceptable techniques for collateral valuation especially in regard to the timely evaluation of securities in investment banking operations; further guidance for setting loan loss provisions; guidelines for risk management practices in foreign exchange related operations including guidelines for requiring written minimum credit policy standards for foreign denominated lending and derivative transactions.

- While specialized on-site examinations are already conducted, authorities are encouraged to conduct additional comprehensive examinations of the major commercial banks.

- Autborities were encouraged to develop regulations and monitoring techniques to assess the unique risks that investment banks can generate. Authorities have enlisted the cooperation of foreign supervisors to ensure the appropriate exchanges of 
information but were cautioned to ensure that international regulatory reporting cooperation provides adequate and timely monitoring capability.

- The CBI was encouraged to examine the design of its liquidity operations and identify any technical deficiencies that may hamper the development of interbank markets.

- Authorities were encouraged to study the possibility of moving to separate reserve requirements for domestic and foreign exchange liabilities and requiring that reserves be met in kind.

- Authorities were encouraged to consider deepening their cooperation with other Nordic supervisors and explore the possibility of establishing specialized teams that can be used as a shared resoutce for on-site examination purposes. 


\section{Iceland: Basic Data}

\section{Denugraphic and other data}

\section{Area}

Population (Dec. 2001)

Natural rate of increase (1992-00)

Life expectancy at birth (1999)

Males

Fernales

Infant mortality (per 1,000 live births)

Population per physician (1997)

GDP per capita (2001, PPP exchange rate)

Composition of GDP in 2001, at current prices

Private consumption

Public consumption

Total investment (including stockbuilding)

Total domestic demand

Exports of goods and services

Imports of goods and services

Selected economic data

Output and unemployment:

Real GDP at market prices

Average unemployment (in percent)

Earnings and prices:

Wage Index

Consumer Price Index

Money and interest rates

M1 (end-period)

3-month Treasury bill yield (eop)

25-year indexed housing bond (real yield)

Fiscal accounts:

General government receipts

General government expenditures

General government balance

(In percent of GDP)

Balance of payments:

Current account balance

(In percent of GDP)

Trade balance

Exports

Impoits

Services and transfers (net)

Gross reserves, official basis

(Millions of SDR, end-period)

Exchange rate (ISK/SDR, end-period)
GDP at market prices

M3 (end-period)

103,000 square kilometers

284,600

1.0 percent

77.5 years

81.4 years

3

308

US\$ 29,196

\begin{tabular}{|c|c|}
\hline $\begin{array}{l}\text { In billions } \\
\text { of kronur }\end{array}$ & $\begin{array}{l}\text { Distributior } \\
\text { in percent }\end{array}$ \\
\hline 417.7 & 55.7 \\
\hline 175.2 & 23.3 \\
\hline 163.1 & 21.7 \\
\hline 756.0 & 100.7 \\
\hline 303.8 & 40.5 \\
\hline 307.3 & 41.0 \\
\hline 750.4 & 100 \\
\hline 1999 & 2001 \\
\hline
\end{tabular}

(Annual percentage change)

$\begin{array}{lcc}3.7 & 5.5 & 3.0 \\ 1.9 & 1.3 & 1.7 \\ & & \\ 6.8 & 6.6 & 8.9 \\ 3.4 & 5.0 & 6.7 \\ & & \\ 19.1 & 3.8 & 0.6 \\ 17.0 & 11.0 & 15.5 \\ 9.8 & 11.8 & 10.0 \\ 4.8 & 6.3 & 5.9\end{array}$

(In billions of kronur)

$\begin{array}{ccc}255.4 & 286.3 & 308.8 \\ 250.7 & 270.0 & 309.9 \\ 14.7 & 16.3 & -1.1 \\ 2.4 & 2.4 & -0.1 \\ & & \\ -42.6 & -67.5 & -33.0 \\ -6.9 & -10.1 & -4.4 \\ -22.4 & -37.5 & -6.1 \\ 144.9 & 149.3 & 196.4 \\ 167.3 & 186.8 & 202.5 \\ -6.1 & -9.5 & 2.6 \\ & & \\ 360 & 311 & 271 \\ 99.6 & 110.4 & 129.4\end{array}$

Sources: Nationat Economic Institute; Central Bank of Iceland; Ministry of Finance; and IFS. 
ICELAND: Fund Relations

(As of April 30, 2002)

I. Membership Status: Joined 12/27/45; Article VIII

II. General Resources Account:

Quota

Fund holdings of currency

Reserve position in Fund

III. SDR Department:

Net cumulative allocation Holdings
SDR Million

117.60

99.02

18.58

SDR Million

16.41

0.07

\author{
\% Quota \\ 100.0 \\ 84.2 \\ 15.8
}

$\%$ Allocation

100.0

0.4

IV. Outstanding Purchases and Loans:

None

V. Financial Arrangements:

None

VI. Projected Obligations to Fund:

Under the Repurchase Expectations Assumptions

(SDR Million; based on existing use of resources and present holdings of SDRs)

Charges/Interest

Total

\begin{tabular}{rrrrr}
\multicolumn{6}{c}{ Forthcoming } \\
\hline 2002 & 2003 & 2004 & 2005 & 2006 \\
\hline 0.3 & 0.4 & 0.4 & 0.4 & 0.4 \\
\hline 0.3 & 0.4 & 0.4 & 0.4 & 0.4
\end{tabular}

VII. Exchange Rate Arrangements: Iceland adopted a floating exchange rate regime for the króna, effective March 28, 2001.

Iceland continues to maintain exchange restrictions pursuant to UN sanctions against Iraq (see EBD/90/242, 7/13/90). Residual restrictions against the Federal Republic of Yugoslavia (Serbia/Montenegro) (see EBD/92/148, 7/17/92) as concerns weapons and other military . equipment will be abolished following the adoption of the UN Security Council's resolution no. 1367 of 10, September 2001.

\section{Last Article IV Consultation:}

Discussions for the 2001 Article IV Consultation were held in Reykjavik during January 1018,2001 . The Staff Report (SM/01/107) was considered by the Executive Board on May 2, $200 \mathrm{l}(\mathrm{EBM} / 01 / 43)$. Article IV consultations with Iceland are currently on the 12-month cycle.

IX. Technical Assistance: None

X. FSAP: An FSAP mission visited Reykjavik from November 8-22, 2000.

XI. Resident Representative: None 


\section{Iceland-Statistical Issues}

Iceland's economic database is comprehensive and sufficient for effective surveillance. Data on a wide range of economic and financial variables are provided to the Fund in a timely manner during and between consultations. Publication of statistical information in English in a timely manner could be improved. The Central Bank introduced major changes to the presentation of the balance sheet in December 1999, causing a temporary discontinuity in the publication of data for the monetary authorities' accounts in IFS. STA is working with the authorities to reconstruct a revised and consistent data presentation.

Iceland has subscribed to the Special Data Dissemination Standard (SDDS) established by the Fund. The only remaining outstanding issue concerns the issuance of a producer price index. In this regard, the authorities have indicated that a producer price index is being developed and will be disseminated according to the SDDS requirements no later than 2003.

As regards the national accounts data, the authorities shifted to ESA95 in August 2000 and revised the corresponding time series back to 1990. Iceland's balance of payments data deviate from the IMF's methodology in the Balance of Payments Manual, fifth edition. Iceland applies the European Central Bank (ECB) methodology for the calculation of income payable by collective investment institutions (e.g., mutual funds). According to the ECB approach, income raised on the asset side of a mutual fund is attributed to the holders of the units over the period under review. Therefore, all income is assigned to investors, regardless of whether it is distributed or not. The non-distributed reinvested part of earnings of mutual funds is estimated and then added to income payable. The latter, however, differs from the IMF's methodology which exempts portfolio investors' shares of retained earnings from the balance of payments statement. This discrepancy in methodology has been subject of written communication between the IMF's Statistics Department (STA) and the ECB. 
Iceland: Core Statistical Indicators

As of May 21, 2002

Date of Latest

Observation

\begin{tabular}{|c|c|c|c|c|c|c|c|c|c|c|c|}
\hline Exchange & $\begin{array}{l}\text { Interna- } \\
\text { tional }\end{array}$ & $\begin{array}{l}\text { Central } \\
\text { Bank } \\
\text { Balance }\end{array}$ & $\begin{array}{l}\text { Reserve' } \\
\text { Base }\end{array}$ & Broad & Interest & $\begin{array}{l}\text { Consumer } \\
\text { Pricc }\end{array}$ & Exports & $\begin{array}{l}\text { Current } \\
\text { Account }\end{array}$ & $\begin{array}{l}\text { Overall } \\
\text { Govern- } \\
\text { ment }\end{array}$ & GDP/ & $\begin{array}{l}\text { External } \\
\text { Debt' } \\
\text { Debt }\end{array}$ \\
\hline Rates & Reserves & Sheet & Money & Money & Rates & Index & Imports & Balance & Balance & GNP & Service \\
\hline
\end{tabular}

\begin{tabular}{|c|c|c|c|c|c|c|c|c|c|c|c|}
\hline $05 / 20 / 02$ & $03 / 31 / 02$ & $03 / 31 / 02$ & $03 / 31 / 02$ & $03 / 31 / 02$ & $03 / 31 / 02$ & May 2002 & Mar. 2002 & 200104 & 2001 & 200104 & 2001 \\
\hline $05 / 20 / 02$ & $04 / 30 / 02$ & $04 / 30 / 02$ & $04 / 30 / 02$ & $04 / 30 / 02$ & $04 / 30 / 02$ & $05 / 15 / 02$ & $04 / 30 / 02$ & $03 / 15 / 02$ & $03 / 19 / 02$ & $03 / 31 / 02$ & $03 / 19 / 02$ \\
\hline Daily & Monthly & Monthly & Monthly & Monthly & Monthly & Monthly & Monthly & Quarterly & Annual & Quarterly & Ouarterly \\
\hline Daily & Monthly & Monthly & Monthly & Monthly & Monthly & Monthly & Monthly & Quarterly & Annual & Quarterly & Quarterly \\
\hline $\begin{array}{l}\text { TRE and } \\
\text { CBI }\end{array}$ & $\mathrm{CB} \mid$ & CBI & $\mathrm{CBI}$ & $\mathrm{CBI}$ & CBI & $\begin{array}{l}\text { Statistics } \\
\text { Iceland }\end{array}$ & $\begin{array}{l}\text { Statistics } \\
\text { Iceland }\end{array}$ & $\mathrm{CBI}$ & $\begin{array}{l}\text { Ministry } \\
\text { of Finance } \\
\text { and NEl }\end{array}$ & $\mathrm{NEI}$ & NEI \\
\hline Electronic & $\begin{array}{c}\text { Electronic } \\
\text { and } \\
\text { Internet }\end{array}$ & $\begin{array}{c}\text { Electronic } \\
\text { and } \\
\text { Internet }\end{array}$ & $\begin{array}{c}\text { Electronic } \\
\text { and } \\
\text { Internet }\end{array}$ & $\begin{array}{l}\text { Electronic } \\
\text { and } \\
\text { Internet }\end{array}$ & $\begin{array}{l}\text { Electronic } \\
\text { and } \\
\text { Internet }\end{array}$ & $\begin{array}{c}\text { Electronic } \\
\text { and } \\
\text { Internet }\end{array}$ & $\begin{array}{l}\text { Electronic } \\
\text { and } \\
\text { Internet }\end{array}$ & $\begin{array}{c}\text { Electronic } \\
\text { and } \\
\text { Internet }\end{array}$ & $\begin{array}{c}\text { Electronic } \\
\text { and } \\
\text { Internet }\end{array}$ & $\begin{array}{l}\text { Internet } \\
\text { and } \\
\text { Public- } \\
\text { ation }\end{array}$ & $\begin{array}{l}\text { Internet } \\
\text { and } \\
\text { Public- } \\
\text { ation }\end{array}$ \\
\hline No & No & No & No & No & No & No & No & No & No & No & No \\
\hline Daily & Monthly & Manthly & Monthly & Monthly & Monthly & Monthly & Monthly & Quarterly & Annual & Quarterly & Quarterly \\
\hline
\end{tabular}

CInternational Monetary Fund. Not for Redistribution 
This page intentionally left blank

CInternational Monetary Fund. Not for Redistribution 


\section{INTERNATIONAL MONETARY FUND}

Public Information Notice

EXTERMAL

RELATIONS

DEPARTMENT

Public Information Notice (PIN) No. $02 / 67$

FOR IMMEDIATE RELEASE

July 3,2002

International Monetary Fund

$70019^{\text {th }}$ Street, NW

Washington, D. C. 20431 USA

\section{IMF Concludes 2002 Article IV Consultation with Iceland}

On June 21, 2002, the Executive Board of the Intermational Monetary Fund (IMF) concluded the Article IV consultation with Iceland. ${ }^{1}$

\section{Background}

The past decade has witnessed a substantial strengthening of the Icelandic economy, due in part to macroeconomic policies that emphasized stability and predictability. The economic expansion was underpinned by the successful disinflation of the early part of the 1990 s and by policies of market liberalization, privatization, and other structural reforms. The rapid growth that took place during the second half of the 1990 s, however, eventually led to overheating and the development of internal and external imbalances. The expansion evolved gradually into a consumption boom fueled by brisk credit growth. Domestic expenditure growth in excess of national income resulted in a widening external current account deficit that peaked at 10 percent of GDP in 2000, and a rekindling of inflationary pressures. The rapid expansion of bank lending-financed mainly by external borrowing for domestic on-lending-led to increased risk exposures and weakened banking sector prudent $/$ al indicators.

Economic developments since eariy 2001 have been characterized by progress in the correction of some of these imbalances. As sentiment turned, the currency depreciated sharply

\footnotetext{
${ }^{1}$ Under Article IV of the IMF's Articles of Agreement, the IMF holds bilateral discussions with members, usually every year. A staff team visits the country, collects economic and financial information, and discusses with officials the country's economic developments and policies. On return to headquarters, the staff prepares a report, which forms the basis for discussion by the Executive Board. At the conclusion of the discussion, the Managing Director, as Chairman of the Board, summarizes the views of Executive Directors, and this summary is transmitted to the country's authorities. This PIN summarizes the views of the Executive Board as expressed during the Executive Board discussion based on the staff report.
}

Washington D,C. 20431 - Telephone 202-623-7100 - Fox 202-623-6772 - www.imf.org 
and growth in economic activity decelerated from $51 / 2$ percent in 2000 to 3 percent in 2001bringing it closer to its long-term sustainable pace. The balance of demand switched swiftly from consumption and other domestic expenditure to net exports and, as a result, the current account deficit fell to about $4 \frac{1}{2}$ percent of GDP. At the same time, however, the twelve-month inflation rate rose rapidly, exceeding the Central Bank of Iceland's (CBI) upper tolerance limit of the target range since June 2001, and stood at 5.9 percent in May 2002. The main cause of irflation has been the pass-through effect of the depreciation, but inflation has also been supported by wage increases that have outpaced prices on average and by a sizable fiscal impulse in 2001 resulting largely from overruns in public wages and other current spending.

Notwithstanding significant stresses in securities and foreign exchange markets and increases in non-performing loans, the banking system maintained profitability during 2001 and increased its capital ratio from 9.9 percent in 2000 to 11.5 percent in 2001 . Progress was made in addressing the weaknesses of the prudential regulatory and supervisory system identified by the 2001 Financial System Stability Assessment (FSSA) report.

The steep depreciation of the króna in 2001 and the attendant inflationary spike hindered the management of monetary policy and consolidation of the new inflation-targeting regime.

In several policy moves, the CBI lowered the policy rate to 8.8 percent: in March 2001 at the time of introduction of the new inflation-targeting regime, in November 2001, and in March-May 2002; mainly on the perception that its monetary policy stance had tightened in real terms. Inflation developments and inflation expectations, however, proved difficult to gauge in 2001 and occasional sterilized interventions in the foreign exchange market failed to contain the depreciation of the krona. In this context, the newly introduced inflation-targeting framework had yet to fully anchor inflation expectations-which on the basis of the January 2002 public survey siood at $61 / 2$ percent.

During the first half of 2002, underpinned by the decline in domestic demand and the turnaround in the trade balance, the monthly inflation rate declined rapidly and the krona appreciated substantially. This led to a significant tightening of moneiary conditions.

The consolidation of public finances turned earlier budget deficits into surpluses, allowing for reductions in net government debt and setting aside funds to cover future public pension obligations. The general government deficit in 2002 is projected at $1 / 2$ percent of GDP, slightly higher than the deficit outturn in 2001 . However, on a cyclically adjusted basis, the 2002 budget represents a fiscal withdrawal, reflecting the objective of a return towards a cyclically adjusted surplus of about 1 percent of GDP over the medium-term.

Current indicators point to an additional moderation in economic activity during 2002 with GDP declining year-on-year by $1 / 2$ percent, bringing output to or slightly below its long-term trend. The redirection of demand and activity towards the external sector is expected to continue as households and businesses, which have both accumulated high levels of indebtedness, consolidate their balance sheets. As a consequence, the current account deficit is projected to contract further to 2 percent of GDP. 


\section{Executive Board Assessment}

Directors commended the authorities for the remarkable growth performance of the Icelandic economy over the last decade. They noted that this performance owed much to the policies, adopted since the early 1990's, of market liberalization; fiscal consolidation; and structural reforms aiming to foster investment, enhance competitiveness, and diversify exports.

Directors welcomed the appreciable progress realized over the past year in redressing the economic imbalances that had developed as a result of the earlier overheating of the economy. They noted, in particular, the reduction of the current account deficit in 2001 and the sharp turnaround of the trade balance in the first half of 2002, resulting from the weakening of domestic demand and the successful redirection of activity toward the extemal sector. Directors noted that these developments had underpinned the stabilization and subsequent appreciation of the króna, and the rapid decline in inflation during 2002.

Against this background, Directors agreed that-after a modest contraction of output this yearthe prospects were for resumption of more balanced growth in late 2002, under the impetus of strong net exports and a gradual recovery of private spending. These developments should bring output close to its long-term trend, while the current account deficit should narrow further toward balance. However, Directors considered that upside risks remained, and that appropriately cautious policies would be necessary to forestall a re-emergence of the earlier imbalances in an economy that still has a quite high level of external debt. In this regard, they noted the high level of resource utilization and the recovery of consumer sentiment. A number of Directors warned that wage demands in export-oriented industries and recent public sector pay increases could spill over to the rest of the economy, posing risks of inflationary pressure. A few speakers also called attention to the possible overheating that could result if several large investment projects materialized.

Directors welcomed the noteworthy progress made by the authorities in addressing the financial sector vulnerabilities identified by the well-timed 2001 FSSA, and their decision to participate in an FSSA follow-up in 2003 . Directors noted the improved profitability of the banking systern and the expansion of its regulatory capital base in 2001-despite adverse financial market developments, the depreciation of the króna, and the slowdown in activity. They welcomed the tightening of prudential regulations and supervision, and the allocation of additional resources to the recently created Financial Supervisory Authority (FSA). Further along these lines, Directors saw a need for strengthening loan classification, provisioning, and collateral valuation standards and monitoring. Also, they advised vigilance regarding emerging securities lending and investment banking activities, and encouraged the authorities to place high priority on the prompt passage of financial legislation, currently under discussion, to expand and strengthen the mandate of the FSA.

Directors supported the inflation-targeting monetary policy regime, and the floating of the króna in March 2001-considering this framework well suited to the circumstances of the icelandic economy. Directors emphasized that monetary policy should be firmly focused on consolidating confidence in this new framework by bringing inflation down to within the tolerance range by end-year, and to the 2.5 percent target in 2003. In light of recent favorable inflation and exchange rate developments, Directors viewed the current monetary policy stance as broadly appropriate. However, with risks to the intended inflation path considered to remain largely on 
the upside, a cautious policy stance would likely be required for some time. Directors stressed that cuts in interest rates needed to be consistent with the CBI inflation forecast, and paced in line with emerging evidence that inflation will stay low even after the effects of one-time measures have worn off. In sum, Directors noted that the CBI should thus stand ready to act symmetrically - delaying, or reversing, the reduction in interest rates, if this proved warranted.

Directors emphasized the importance of nurturing the newly accorded independence of the CB 1 , as well as the predictability and transparency of the inflation-targeting system. In this connection, several Directors suggested that the authorities consider publishing a calendar of the monetary policy meetings of the Board of Governors of the CBI, and in addition, the detailed considerations that led to policy decisions. They also advised considering reforms of the CBI's liquidity facilities, with a view to encouraging banks to resort to the interbank market and avoiding money market distortions.

Directors agreed that the public finances and the authorities' medium-term fiscal plans were essentially sound, but they expressed concern about the slippages in current spending that had taken place in recent years. They supported the authorities' goal of rapidly returning to moderate budget surpluses and reducing government liabilities, in order to provide a necessary buffer against external shocks. They suggested that, in working toward those goals, more emphasis be placed on budgetary discipline and restraint in current spending-including notably the government wage bill-and less on cuts in capital spending, which they saw as crucial for maintaining infrastructure and safeguarding the basis for long-term growth. Directors recommended that the fiscal policy framework be reinforced by introducing mult-year budget plans with explicit expenditure limits and cyclically-adjusted balance targets, as well as budgetary accounting and coverage that conform to established national accounts methodology.

Directors commended the authorities' consistent pursuit of growth-oriented structural reforms. They supported efforts at reforming the tax system to foster saving and minimize economic distortions while bringing corporate taxation closer to international practices. They also welcomed the resumption of the privatization process, as well as the decision to continue devoting the proceeds mainly to redeeming public debt. The authorities were encouraged to introduce more flexibility in the wage settlement process to better reflect productivity differentials. Most Directors also suggested that they should consider expanding the role of the private sector in the provision of public services such as health and education.

Directors welcomed the authorities' efforts to combat money laundering and the financing of terrorism. They noted that Iceland has a well-developed system to fight financial crime, including provisions on customer identification, reporting of unusual transactions, regulations to seize assets, and training of the staff of financial institutions. Directors welcomed the passage of legisiation by the parliament to implement the United Nations resolutions and conventions related to terrorism.

Directors welcomed the granting of tariff concessions to least developed countries similar to those that apply to members of the European Economic Area, and the removal of tariffs on most imports of agricultural products; but they noted the high level of agricultural subsidies and called for a plan to reduce the protection accorded to this sector. They welcomed the authorities' 
commitment to increase official development assistance and encouraged progress toward the United Nations target of 0.7 percent of GNP.

Iceland publishes statistical data on a sufficiently timely and comprehensive basis to permit effective surveillance.

Public Information Notices (PINs) are issued, (i) at the request of a member country, following the conclusion of the Article IV consultation for countries seeking to make known the views of the IMF to the public. This action is intended to strengthen IMF surveillance over the economic policies of member courtries by increasing the transparency of the IMF's assessment of these policies; and (ii) following policy discussions in the Executive Board at the decision of the Board. The Staff Report for the 2002 Article IV Consultation with lceland is also available. 
Iceland: Selected Economic Indicators

Real Economy (change in percent)

Real GDP

$\begin{array}{rrrrr}5.0 & 3.6 & 5.5 & 3.0 & -0.5 \\ 12.7 & 4.0 & 6.6 & -2.5 & -2.9 \\ 1.7 & 3.4 & 5.0 & 6.7 & 5.2 \\ 2.8 & 1.9 & 1.3 & 1.7 & 2.3 \\ 29.6 & -3.4 & 14.7 & -6.2 & -13.0\end{array}$

Domestic Demand

5.0

CPI

Unemployment Rate (in percent)

(2)

General Government Finances (percent of GDP)

Financial Balance 2/

$\begin{array}{rrrrr}0.5 & 2.4 & 2.4 & -0.1 & -0.5 \\ 2.1 & 3.8 & 2.3 & 0.1 & 1.4 \\ 48.9 & 44.2 & 41.6 & 46.8 & 41.9\end{array}$

Gross Debt

48.

30.4

27.6

15.2

7.3

$\mathrm{CB}$ | policy rate (period average, in percent)

Balance of Payments (in percent of GDP)

Trade balance

Current account balance

Financial and capital account

Gross exiernal debt

Reserve Cover (in months of imports) 3/

Fund Position (as of April 30, 2002)

Holdings of currency (in percent of quota)

Holdings of SDRs (in percent of allocation)

Quota (in millions of SDRs)

Exchange Rate

Exchange Rate Regime

Present Rate (May 17, 2002) 4/

Nominal effective rate (change in percent)

Real effective rate (change In percent)

$\begin{array}{rrrrr}-4.4 & -3.6 & -5.6 & -0.8 & 0.8 \\ -7.0 & -6.9 & -10.1 & -4.4 & -2.0 \\ 8.0 & 9.8 & 10.5 & 5.4 & \ldots \\ 72.4 & 84.5 & 108.9 & 124.3 & \ldots \\ 1.6 & 1.8 & 1.5 & 1.4 & \ldots\end{array}$

84.2

0.4

117.6

Sources: National Economic Institute; Central Bank of Iceland; Ministry of Finance; and IMF staff estimates.

1/ Projaction

2/ National accounts basis.

$3 /$ In months of imports of goods and services

4/ Trade weighted exchange rate index of the króna $(12 / 31 / 1991=100)$. 


\section{Statement by Ólafur Ísleifsson, Executive Director for Iceland June 21, 2002}

My Icelandic authorities would like to thank Mr. Escolano and his team for their reports and the constructive discussions with the Fund mission during their visit. My authorities are in broad agreement with the main conclusions of the staff report. I would like to draw attention to some recent developments and prospects and a few policy issues.

\section{Recent developments and prospects}

Following several years of rapid growth through 2000 the Icelandic economy slowed down significantly in 2001, mostly due to declining private consumption and investment. Exports continued to grow and, as a result, the current account deficit fell from $10.2 \%$ to $4.3 \%$. This adjustment process followed the build-up of private debt by households and businesses during the upswing. A rapid depreciation of the kronna exchange rate during 2001 added further momentum to this development and led to a substantial, but temporary, hike in inflation.

This year, the economy has continued to cool down and inflation has declined rapidly, the 12 month rate fell to $4.8 \%$ in June after peaking at $9.4 \%$ in January. In the Central Bank's assessment, the seasonally adjusted underlying inflation rate has in recent months been in the neighborhood of $3 \%$. Furthermore, the króna has continued to appreciate, boosted by the sharply shrinking current account deficit. The current account deficit is expected to fall below $2 \%$ of GDP this year. Private consumption and gross fixed investment have contracted significantly from last year, and domestic demand is expected to remain subdued for the remainder of the year. However, a buoyant external sector has softened the impact of the adjustment of the domestic sector. Business profitability appears strong in general, but business investment as well as private consumption will continue to be constrained by a relatively heavy debt service burden.

According to the latest inflation forecast of the Central Bank, inflation will fall within the tolerance limit later this year and be in line with the Bank's inflation target late next year, as envisaged when the inflation target was adopted. However, my authorities agree with staff that monetary restraint should be eased cautiously as the continued decline in inflation is further confirmed. At present, the monetary stance still imposes considerable restraint on activity, as reflected by a policy rate in real terms of up to $6 \%$ in recent months.

\section{Fiscal policy}

The main message of the staff report regarding the public finances is that they are sound. The slowdown in the global economy as well as the fall in domestic demand affected government revenues. Nevertheless, the public finances have been sound and the tight overall fiscal stance has contributed to stabilizing the economy. The Government has pursued a policy 
which aims at fiscal consolidation and debt reduction and intends to achieve a structural budgetary surplus of about 1 per cent of GDP over the medium term. The Government plans to continue to use privatization proceeds to teduce net government debt.

My authorities agree with the staff that reforms of the fiscal framework would strengthen budgetary discipline and improve the transparency and predictability of fiscal policy. In this context, my authorities have been looking towards introducing multi-year budget plans with explicit expenditure limits and cyclically-adjusted balance objectives. My authorities agree with staff that a medium-term strategy of fiscal consolidation would be helpful and could contribute to containing current spending in coming years.

\section{Monetary policy}

The staff concludes that monetary conditions, while broadly appropriate at present, were largely accommodative during the past year. This conclusion is based on the mission's assessment that real interest rates were low or at times even negative as calculated on the basis of past inflation. It is true that the monetary stance was ex post not as firm as intended, basically due to the fact that the króna fell much more than expected, causing a temporary unanticipated surge in the rate of inflation. The stance of monetary policy therefore should be viewed from a broader perspective. The depreciation of the króna from the peak in April 2000 to the trough in November 2001 was mainly brought about by contractionary forces, diminishing capital inflows and a lack of confidence in the domestic economy. The remarkably swift current account reversal over the course of 2001 and contraction in domestic demand suggest that monetary conditions were not overly accommodative, even if less restrictive than intended.

The exchange rate depreciation in 2001 had the potential to undermine price stability. The appreciation of the króna since November 2001 has therefore been important. In view of the current account reversal and other changes in underlying fundamentals, the appreciation of the króna appears sustainable. While the króna may have been slightly overvalued in 2000 , my authorities do not consider this overvaluation to have been a major force behind last year's decline, as may be concluded from the staff report.

My authorities take note of the staff's suggestions of ways to improve the operational procedures of the monetary framework. My authorities broadly agree with the staff on the need to address imperfections in the money market. The recently established foreign currency swap market and steps taken to improve the Bank's ability to forecast liquidity demand serve towards this purpose.

The new monetary regime was installed at the end of March last year and the independence of the Central Bank was subsequently confirmed in a new Central Bank Act. In the course of 2001 there was considerable pressure at times from various parts of society for an easing of monetary policy. The current legislation and the Bank's analytical capacity, however, make it well equipped to withstand such pressures. The Bank's monetary policy decisions since the adoption of the new regime have been backed by its own analysis. The staff suggests pre- 
announced monetary policy meetings. In the initial phases of the new monetary policy regime, the Bank has found the flexibility of the current practice of some value. However, as the new framework becomes more established, the Board of Governors may consider to move towards deciding in advance and officially announce a meeting calendar.

\section{Structural reforms}

My authorities would like to highlight two structural issues. The first is the recently implemented tax reforms, effective as of 2002 , which serve to simplify the tax system, improve efficiency by reducing distortions and encourage saving as rightly pointed out in the staff report and further highlighted in the Selected Issues paper. The tax reform is an important element of the structural reform process and will set the Icelandic tax system in line with neighboring countries and thus improve the competitive position of Icelandic enterprises.

Second, last week, one-fifth of the shares in the larger of the two commercial banks with majority state ownership were offered in a general sale. With all the shares in the offering being sold, the Government is no longer a majority stakeholder in the bank. This operation will no doubt have a catalytic effect on the privatization process after a slight interlude and further steps will be taken later this year.

\section{Financial sector policies}

The staff report recognizes the progress and improvements that have been made in the regulatory framework and in supervisory resources and activities by the Financial Supervisory Authority (FSA) over the last year. The FSA intends to further strengthen the accounting rules covering the assessment of loans and advances of credit institutions. Concerns regarding securities lending have already been taken into consideration by the FSA, inter alia by improving information collection in that area. The FSA also recognizes the importance of issues related to connectedness in the financial market and is currently making an effort in that field. Furthermore, in the supervisory work of the FSA in the period ahead, a special focus will be placed on investment banking activities.

Important progress has been made in improving the observance of the CPSS Core Principles for Systematically Important Payment Systems since the preparation of the FSSA report. Measures necessary to ensure full compliance with these principles have been identified and a plan has been adopted for their implementation. Full compliance with all the principles is envisaged in Spring 2003.

In the spring session of parliament, an act was adopted providing for the necessary legal amendments in order to ratify two recent UN conventions on the financing of terrorism. For this purpose the penal code has been amended accordingly.

As mentioned in the report, my authorities have been working on a comprehensive legislative package on banking, securities, and financial market regulation. The draft legislation is in the final stages of preparation. 